\section{masurasanum ANALISIS DE COYUNTURA}

Revista Venezolana de Análisis de Coyuntura ISSN: $1315-3617$

coyuntura@cantv.net

Universidad Central de Venezuela

Venezuela

Hausmann, Ricardo; Panizza, Ugo; Stein, Ernesto

Why do countries float the way they float?

Revista Venezolana de Análisis de Coyuntura, vol. VI, núm. 2, julio-diciembre, 2000, pp. 11-55

Universidad Central de Venezuela

Caracas, Venezuela

Available in: http://www.redalyc.org/articulo.oa?id=36460202

How to cite

Complete issue

More information about this article

Journal's homepage in redalyc.org

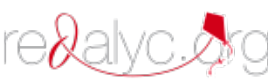

Scientific Information System Network of Scientific Journals from Latin America, the Caribbean, Spain and Portugal Non-profit academic project, developed under the open access initiative 


\title{
WHY DO COUNTRIES FLOAT THE WAY THEY FLOAT?
}

\author{
Ricardo Hausmann, Ugo Panizza and Ernesto Stein* \\ RESEARCH DEPARTMENT. INTER-AMERICAN DEVELOPMENT BANK
}

\begin{abstract}
:
Countries that are classified as having floating exchange rate systems (or very wide bands) show strikingly different patterns of behavior. They hold very different levels of international reserves and allow very different volatilities to the movements of the exchange rate relative to the volatility that they tolerate either on the level of reserves or on interest rates. We document these differences and present a model that explains them as the optimal response of a Central Bank that attempts to minimize a standard loss function, in an environment in which firms are credit-constrained and incomplete markets limit their ability to avoid currency mismatches. This model suggests that the difference in the way countries float cold be related to their differing levels of exchange rate pass-through and the differing ability to avoid currency mismatches. We test these implications and find a very strong and robust relationship between the pattern of floating and the ability of a country to borrow internationally in its own currency. We find weaker and less robust evidence on the importance of pass-through to account for differences across countries with respect to their exchange rate/monetary management.
\end{abstract}

Keywords: Exchange rate, Emerging Markets, Dollarization.

\section{INTRODUCTION}

During the last few years, there has been a substantial increase in the number of countries that have adopted flexible exchange regimes. However, countries that are formally classified as having floating exchange rate regimes (or very wide bands) show remarkable differences regarding the way in which they manage exchange rate policy. They hold very different levels of international reserves, show different propensities to intervene in the foreign exchange

*Hausmann is the Chief Economist of the Inter-American Development Bank, Panizza, and Stein are economists in the Research Department of the Inter-American Development Bank, 1300, New York Ave. NW, 20577 Washington, D.C. Email: RICARDOH@IADB. ORG; UGOP@IADB.ORG; ERNESTOS@IADB.ORG. We would like to thank Patricia Cortés for excellent research assistance and Eduardo Fernandez Arias, Michael Gavin, participants to the Inter-American Seminar in Economics held at CEMA and seminars at IDB and LACEA Winter Camp for very helpful comments. We are also grateful to Melissa Fiorelli, Denis Petre and Rainer Widera for making unpublished BIS data available. All remaining errors are our own. The views expressed here are those of the authors, and do not necessarily reflect those of the Inter-American Development Bank. 
market, and allow very different degrees of exchange rate flexibility in response to shocks.

Standard textbook discussions of exchange rate regimes emphasize that the main advantages of flexibility derive from the ability to respond to shocks with an independent monetary policy. These discussions emphasize the role of monetary policy for output stabilization. More recently, there has been a growing consensus among economists and policymakers suggesting that countries that decide to adopt a floating regime should use monetary policy to target inflation. In particular, Svensson (1997) has formally shown the optimality of inflation targeting implemented through a "Taylor rule" in which interest rate adjustments depend on changes in inflation and output. However, Ball (1998) has shown that, while inflation targeting and standard Taylor rules are appropriate for closed economies, this may not be the case for open economies in which the passthrough from exchange rate to prices is high. In particular, he shows that, because of its effect on prices, monetary authorities should also be concerned about the exchange rate. While Ball emphasizes the role of exchange rate passthrough, recent work by Aghion et al. (2000) and Bacchetta (2000) suggests an alternative reason to be concerned with exchange rate when conducting monetary policy: the presence of foreign currency debt in the balance sheet of firms. They show that when firms hold a large fraction of their debt in foreign currency, monetary policy becomes increasingly complex. This is due to the fact that, while reductions in interest rate can have an expansionary effect through a credit channel, the depreciation brought about by the interest rate reduction can be contractionary through a balance sheet channel.

In this paper, we document the main differences in exchange rate management among countries that have formally adopted flexible exchange rate regimes ${ }^{1}$. We concentrate on three different aspects of exchange rate management: the stock of reserves, the relative volatility of exchange rates vis a vis reserves, and the relative volatility of exchange rates vis a vis interest rates. We then present a model that explains these differences by emphasizing both the role of exchange rate pass-through (as in Ball, 1998) and the role of liabilities denominated in foreign currency (as in Aghion et al, 2000). In particular we model the behavior of a Central Bank that attempts to minimize a standard BarroGordon loss function in an environment in which depreciations lead to inflation, and firms are credit-constrained and have currency mismatches in their balance sheets. High levels of exchange rate pass-through may lead the Central Bank to

\footnotetext{
${ }^{1}$ Other papers which have highlighted differences across countries under similar exchange rate regimes include Levy Yeyati and Sturzenegger (1999), Calvo and Reinhart (2000), and Edwards and Savastano (1999).
} 
be more concerned about exchange rate movements. Similarly, the existence of important currency mismatches in the economy may lead the Central Bank to limit exchange rate volatility, as depreciations can hurt those exposed to foreign currency liabilities and thus affect output.

After constructing measures of pass-trough, as well as the ability of countries to avoid currency mismatches in their balance sheets, we test the implications of the model. Using a sample of 30 countries with de facto floating exchange rate regimes or wide bands, we find a very strong and robust relationship between a country's pattern of floating and its ability to borrow internationally in its own currency, which we use as an indicator of ability to avoid currency mismatches. More specifically, countries that can borrow abroad in their own currency tend to keep a smaller stock of reserves, and allow a higher volatility of exchange rates vis a vis reserves or interest rates. We find weaker and less robust evidence on the importance of exchange rate pass-through as a determinant of differences across countries regarding their exchange rate management.

The paper is organized as follows. Section 2 documents the differences in exchange rate management among countries that formally have floating exchange rate regimes or wide bands. Section 3 briefly discusses the theoretical model, based on Aghion et al (1999), which is derived formally in the Appendix It then presents our main explanatory variables, the degree of exchange rate passthrough and the ability of countries to borrow in their own currency, and empirically tests the implications of the model. Finally, Section 4 concludes.

\section{HOW DO FLOATERS FLOAT?}

In this section, we document important differences in the behavior of countries that formally have floating exchange rate regimes or wide bands, regarding the management of the exchange rates. It is important first to define the sample of countries that will be studied. For this, we worked with the IMF classification of exchange rate regimes, using the November 1999 issue of the IFS (which corresponds to regimes as of June $30^{\text {th }}, 1999$ ). The countries in our sample correspond to the following categories from the Exchange Arrangements classification of the IMF:

- Independently floating: as of June 1999, there were 48 countries classified under this label. More than half of these countries, however, are very small economies, mostly in Africa and the Middle East. Since our interest is to look at the behavior of floaters in Latin America as 
compared to developed and emerging market economies, we restrict the sample to exclude such small countries ${ }^{2}$. The 17 countries we do include from this group are the following: Australia, Brazil, Canada, India, Indonesia, Japan, Korea, Mexico, New Zealand, Peru, Philippines, South Africa, Sweden, Switzerland, Thailand, United Kingdom, and the United States. To this group, we add Germany, which is classified as part of a monetary union (the Euro Area) but which can be considered to be floating independently vis a vis the dollar.

- Managed floating with no preannounced path for exchange rate: For the same reasons as above, out of 25 countries in this category, we include in our sample the following seven: the Czech Republic, the Dominican Republic, Guatemala, Jamaica, Norway, Paraguay, and Singapore.

- Exchange rate with crawling or horizontal bands: From this group, we only include countries in which the width of the band was at least 18 $\%$, in order to provide sufficient flexibility. The five countries included under this last category are Colombia (crawling band of $\forall 9 \%$ ), Chile (crawling band of $\forall 16 \%$ ); Greece (horizontal band of $\forall 15 \%$ ), Israel (crawling band of $\forall 15 \%$ ) and Poland (crawling band of $\forall 12.5 \%$ ). Of these countries, Chile and Colombia have more recently adopted independently floating exchange rate regimes.

As a result, our sample includes 30 countries: the G-3 (the US, Germany and Japan); nine other industrial countries (Australia, Canada, Greece, Israel, New Zealand, Norway, Sweden, Switzerland, and the United Kingdom); nine Latin American and Caribbean countries (Brazil, Chile, Colombia, Dominican Republic, Guatemala, Jamaica, Mexico, Paraguay and Peru); and nine other developing countries (the Czech Republic, Korea, Philippines, Indonesia, India, Poland, Singapore, South Africa and Thailand). For some purposes, we will later divide the two last groups into emerging countries and other developing countries.

\footnotetext{
2 There are 30 countries which we exclude from the independently floating category. These are Afganistan, Albania, Angola, Armenia, Congo, Eritrea, Gambia, Georgia, Ghana, Guinea, Guyana, Haití, Kazajstán, Liberia, Madagascar, Mauritius, Moldova, Mongolia, Mozambique, Papua New Guinea, Rwanda, Santo Tomé y Príncipe, Sierra Leona, Somalía, Sudán, Tanzanía, Uganda, Yemen Republic, Zambia, and Zimbabwe. We also excluded Ecuador, since it only adopted (briefly) a floating regime in February 1999 , in the context of a crisis, and has since moved on to dollarization.
} 
In what follows, we describe how the different countries behave by focusing on three aspects of their exchange rate management: a) the stock of reserves with which they float; b) the extent to which they use these reserves to stabilize the exchange rate; and c) the extent to which they use interest rates to stabilize the exchange rate.

\subsection{The stock of reserves: some countries float with lifejacket}

One of the dimensions in which floating countries differ very substantially is the level of reserves they maintain. A country that floats without regard for the level of the exchange rate does not need a lot of reserves to manage the exchange rate. In contrast, countries which for some reason are not willing to let the exchange rate take any level need a large cushion of reserves to conduct exchange rate policy.

The first column of Table 1 presents the level of reserves in each of the countries in our sample, normalized in each case by broad money (M2). The value of reserves corresponds to the average from April 1998 through April 1999. The table shows very substantial differences across countries. Most striking is the high level of reserves held by emerging country floaters, as compared to industrialized floaters. While countries such as Singapore, Peru and Chile have reserves that exceed $50 \%$ of $\mathrm{M} 2$, most industrial countries keep a stock of reserves below $10 \%$ of $M 2$. The differences in this dimension are clearly illustrated at the bottom of Table 1. On average, emerging market floaters keep reserves equivalent to $38 \%$ of $\mathrm{M} 2$, six times as much as do G-3 floaters, and more than twice as much as other industrial countries ${ }^{3}$. The level of reserves in emerging countries is even higher than that in non-emerging developing countries. In general, these results support Calvo's argument that emerging countries seem to be floating "with lifejacket". It is interesting to note that Argentina and Uruguay, perhaps the two countries in Latin America that have a stronger commitment in terms of their exchange rate, have levels of reserves below those of most of their floating counterparts in Latin America ${ }^{4}$.

\footnotetext{
${ }^{3}$ We define as emerging markets the following countries: Brazil, Chile, Colombia, Czech Republic, South Korea, Mexico, Peru, Philippines, Poland, Singapore, South Africa, and Thailand.

${ }^{4}$ Reserves/M2 are approximately $28 \%$ in the case of Argentina, and $20 \%$ in the case of Uruguay.
} 


\begin{tabular}{|c|c|c|c|c|c|c|}
\hline \multirow{3}{*}{ Countries } & \multirow{2}{*}{\multicolumn{2}{|c|}{$\begin{array}{c}\text { International reserves } \\
\text { over M2 }\end{array}$}} & \multicolumn{4}{|c|}{$\begin{array}{c}\text { Volatility of depreciation divided by volatility } \\
\text { of: }\end{array}$} \\
\hline & & & \multicolumn{2}{|c|}{ International reserves } & \multicolumn{2}{|c|}{ Interest rate } \\
\hline & Level & Rank & Level & Rank & Level & Rank \\
\hline AUSTRALIA & 0.06 & 25 & 6.91 & 5 & 90.21 & 3 \\
\hline BRAZIL & 0.25 & 14 & 2.92 & 8 & 12.13 & 24 \\
\hline CANADA & 0.06 & 26 & 3.37 & 7 & 23.46 & 12 \\
\hline CHILE & 0.49 & 3 & 0.42 & 25 & 7.96 & 27 \\
\hline COLOMBIA & 0.41 & 5 & 0.93 & 19 & 8.48 & 26 \\
\hline CZECH REPUBLIC & 0.31 & 8 & 1.26 & 16 & 13.97 & 20 \\
\hline DOMINICAN REPUBLIC & 0.09 & 23 & 1.58 & 14 & 11.57 & 25 \\
\hline GERMANY & 0.11 & 21 & 2.84 & 9 & 157.91 & 2 \\
\hline GREECE & 0.36 & 6 & 0.39 & 28 & 25.02 & 9 \\
\hline GUATEMALA & 0.30 & 9 & 0.42 & 26 & 24.94 & 10 \\
\hline INDIA & 0.13 & 20 & 1.21 & 17 & 3.70 & 29 \\
\hline INDONESIA & 0.34 & 7 & 2.15 & 13 & 23.38 & 13 \\
\hline ISRAEL & 0.26 & 12 & 0.76 & 21 & 21.38 & 15 \\
\hline JAMAICA & 0.25 & 15 & 0.27 & 30 & 2.75 & 30 \\
\hline JAPAN & 0.05 & 28 & 30.45 & 1 & 377.26 & 1 \\
\hline KOREA SOUTH & 0.24 & 16 & 1.35 & 15 & 14.14 & 19 \\
\hline MEXICO & 0.30 & 10 & 0.84 & 20 & 6.99 & 28 \\
\hline NEW ZEALAND & 0.06 & 27 & 12.68 & 4 & 23.78 & 11 \\
\hline NORWAY & 0.29 & 11 & 0.36 & 29 & 12.34 & 23 \\
\hline PARAGUAY & 0.26 & 13 & 0.62 & 23 & 12.38 & 22 \\
\hline PERU & 0.64 & 2 & 0.51 & 24 & 13.13 & 21 \\
\hline PHILIPPINES & 0.24 & 17 & 2.32 & 11 & 38.50 & 8 \\
\hline POLAND & 0.45 & 4 & 0.42 & 27 & 14.58 & 18 \\
\hline SINGAPORE & 0.88 & 1 & 0.69 & 22 & 20.00 & 16 \\
\hline SOUTH AFRICA & 0.06 & 24 & 2.47 & 10 & 22.80 & 14 \\
\hline SWEDEN & 0.14 & 19 & 0.98 & 18 & 62.59 & 5 \\
\hline SWITZERLAND & 0.09 & 22 & 2.27 & 12 & 40.43 & 7 \\
\hline THAILAND & 0.23 & 18 & 6.62 & 6 & 15.16 & 17 \\
\hline UNITED KINGDOM & 0.02 & 29 & 17.95 & 3 & 46.54 & 6 \\
\hline \multirow[t]{2}{*}{ UNITED STATES } & 0.01 & 30 & 19.38 & 2 & 69.63 & 4 \\
\hline & \multicolumn{6}{|c|}{ Averages by country grouping } \\
\hline G3 & 0.06 & & 17.55 & & 201.60 & \\
\hline OTHER & & & & & & \\
\hline INDUSTRIALIZED & 0.15 & & 5.07 & & 38.42 & \\
\hline EMERGING & & & & & & \\
\hline COUNTRIES & 0.37 & & 1.76 & & 15.65 & \\
\hline OTHER DEVELOPING & 0.21 & & 0.82 & & 11.06 & \\
\hline LAC EMERGING & 0.42 & & 1.12 & & 9.74 & \\
\hline EAST ASIA & 0.39 & & 2.63 & & 22.23 & \\
\hline ALL COUNTRIES & 0.25 & & 4.18 & & 40.57 & \\
\hline
\end{tabular}

\subsection{Stabilizing exchange rates with reserves}

To what extent do floaters attempt to stabilize exchange rates by intervening in the foreign exchange market? In order to answer this question, we look at the relative volatilities of the exchange rate and of reserves. We work with relative 
volatilities, because comparisons based solely on the volatility of exchange rates alone, or of reserves alone, could be misleading. Comparing exchange rate volatilities does not provide a complete idea of the willingness of a country to defend its parity. The exchange rate in a country could be more volatile than that in another simply because it is subject to larger external shocks, even if the authorities intervene heavily to keep the exchange rate within certain limits. Comparing volatility of reserves may be problematic too. Reserves may be very stable during a period due to the absence of shocks, even in a country that would intervene heavily if a shock warrants it. A possible drawback of using relative volatilities is that one does not know if the ratio is high because of the numerator being unusually high, or the denominator unusually low. For this reason, Table $1 \mathrm{~A}$ in the appendix presents the volatility of reserves, and that of exchange rates country by country, as well as the ranking of the countries in the sample according to each of these measures.

As a measure of exchange rate volatility, we use the standard deviation of the rate of depreciation ${ }^{5}$. As a measure of the volatility of reserves, we use the standard deviation of the stock of reserves, normalized by the dollar value of the stock of broad money (M2). In order to avoid changes in the exchange rate from affecting the measured volatility of reserves through the dollar value of $M 2$, the monetary aggregate is averaged over the period under consideration. More precisely, the indicator of the degree to which countries intervene in the foreign exchange markets using reserves is given by:

$$
\operatorname{std}(D E P) / \operatorname{std}(R E S / \overline{M 2}) \text {. }
$$

This indicator provides information about how flexible exchange rate regimes are in reality. Under a truly fixed exchange rate regime or a crawling peg with a constant rate of crawl, the standard deviation of devaluations would be zero. Therefore, our indicator would take a value of zero as well. In a purely floating regime, in which there is no foreign exchange intervention at all, the denominator would be 0 , and our index would tend to infinity. The value of the index can give

\footnotetext{
${ }^{5}$ We prefer this measure to the volatility of the exchange rate, since it is possible that the (implicit) objective of the intervention is to achieve a crawling peg with a fairly constant rate of crawl, rather than simply to keep the exchange rate at a certain level. We also worked with an alternative index of foreign exchange intervention, which considers the volatility of changes in reserves rather than levels. The results are very similar, and are therefore not reported here.
} 
us a good indication of the degree to which, independently of the formal classification, the regime is "de facto" floating or not ${ }^{6}$.

In calculating our foreign exchange intervention indicator, an important aspect is to define which exchange rate should be used in the calculations for each country. While the exchange rate vis a vis the US dollar is the natural one to use in most cases, there are some cases in which the exchange rate vis a vis other currencies is more appropriate. For the case of countries in Europe, we use the exchange rate against the Mark as a basis for our calculations. In the case of New Zealand, we use the Australian dollar, since the links to this currency are much stronger than those to the US dollar. In the case of the United States, we used the nominal effective exchange rate as the basis for our indicators. In all other cases, we used the exchange rate with respect to the US dollar ${ }^{7}$.

The second column of Table 1 shows the results of our index of foreign exchange intervention. For most countries, the values of the index correspond to the period January 1997-April 1999 (or until the latest month available from IFS). In the case of countries which abandoned fixed or intermediate exchange rate regimes after January 1997, we chose to start the period of measurement three months after the regime shift, in order to exclude the initial period, so as to give the exchange rate enough time to stabilize at a new level ${ }^{8}$.

As with the stock of reserves, the differences among floating countries are striking. The relative volatility of exchange rates vis a vis that of reserves is very large in Japan, the United States and the UK, suggesting that these countries are very close to a pure float. Germany and Australia also show high values for this index. At the other end of the spectrum, we find a mix of countries that seem to intervene substantially in the foreign exchange market, demonstrating a behavior closer to that of fixed regimes. Some of them are from Latin America (Chile, Guatemala, Peru and Paraguay), while others are the countries of the European Union that have not joined the Euro (Greece, Norway, and Sweden), which show a preference to keep their exchange rates vis a vis their neighbors very stable. Among the East Asian floaters, Singapore is the one that seems to intervene the most. Interestingly, the set of countries at the lower extreme of the index includes countries with wide bands (such as Greece and Chile), countries under managed floating regimes (such as Guatemala, Norway, Paraguay and Singapore) and countries which are labeled as independent floaters (Sweden, and Peru).

\footnotetext{
${ }^{6}$ Sturzenegger and Levi Yeyati (1999) use volatility of reserves and exchange rates in order to classify countries according to their "de facto" regimes.

${ }^{7}$ Data on exchange rates and on reserves was taken from IFS.

${ }^{8}$ In the case of Indonesia, we started 5 months after the regime shift in order to avoid a period of extreme instability.
} 
At the bottom of Table 1 we show the index, averaged according to country groups. The index for the emerging countries is one tenth that corresponding to the G-3, one half that of other developed floaters, and twice the size of that in other developing countries. This clearly shows that the ability to float freely is closely associated to the level of development. Among the emerging floaters, those in East Asia seem to be closer to the ideal float, in comparison to the Latin American countries. However, with the exception of Indonesia and Thailand, even these countries are very far from de facto independent floating.

\subsection{Stabilizing exchange rates with interest rates}

In the previous section we focused on one of the variables that monetary authorities can use to manage exchange rates: the reserves. But intervention in the foreign exchange market is not the only channel that monetary authorities have in order to influence movements in the exchange rate. They can also affect it by tightening or loosening monetary policy. Thus, in this section we will look at the relative volatility of exchange rates and interest rates as another indicator of the degree to which economic authorities are willing to let the exchange rate float freely.

As was the case with our previous indicator, if exchange rates are fixed or follow a crawling peg with a constant rate of crawl, this indicator would be zero. Low values of this indicator would suggest that exchange rates are very stable relative to interest rates. This could be due to attempts by the monetary authorities to stabilize exchange rates using interest rates. Admittedly, interest rates could be used for other purposes, namely output stabilization, but it would be hard to argue that the high volatility of interest rates we see in most emerging countries could be due to this motive.

Some authors such as Levi Yeyati and Sturzenegger (1999) have suggested that, while wide movements in interest rates may be an indication of heavily managed exchange rates, they are also consistent with floating regimes coupled with inflation targets, particularly in countries in which the exchange rate passthrough is high. While this "observational equivalence" may be a concern when trying to classify countries into different regimes, it does not pose a problem here. We want to show that different countries float in different ways. For our purposes, it is not important to know if there is a concern about exchange rates per-se. What matters is whether authorities act "as if" that concern existed.

In addition to these more conceptual points, examples abound of countries that have in fact used interest rates actively in order to avoid the depreciation of the currency. The behavior of some European countries before the 1992 collapse 
of the EMS is a case in point. The increase in Brazilian interest rates prior to the collapse of the Real is a recent Latin American example. These considerations justify the focus on the behavior of interest rates as a variable of interest.

In order to compute the relative volatility of devaluations vis a vis interest rate, we used, when available, money market interest rates from IFS. In cases in which these rates were unavailable, we used data on money market rates from Bloomberg and, when these were unavailable or the series not long enough, we replaced money market rates with lending or deposit rates from IFS ${ }^{9}$. As was the case with the reserves, the index corresponds to the period January 1997-April 1999 (or until the latest month available from IFS), except for those countries which abandoned fixed exchange rate regimes after January 1997, in which case we started the period of measurement three months after the regime shift.

The relative volatility of devaluations vis a vis interest rate is presented in the third column of Table 1 . As in the case of our other measures, there are very substantial differences across countries. Japan is by far the country with the highest ratio. Table A1 in the Appendix shows that the volatility of exchange rates in this country is not unusually high, but the volatility of interest rates is well below that of all other countries. In the G-3 countries as a group, the ratio of volatilities is one order of magnitude larger than in the case of emerging countries, while in other developed countries the ratio is more than twice as large. Interestingly, the ratio is very low in most countries in Latin America, whether they are classified as emerging or other developing. In fact, eight out of the ten countries with the lowest ratios are from this region.

\section{WHY DO COUNTRIES FLOAT THE WAY THEY FLOAT?}

In this section, we attempt to uncover some of the reasons for the difference in behavior among floaters discussed in Section 2 . We focus on two separate

\footnotetext{
${ }^{9}$ Rather than working with annual interest rates, for the calculation of the volatility of interest rates we converted annual rates into monthly rates. The reason is the following: if a country has, during the period under study, a downward trend in inflation, this will translate into a downward trend in interest rates, as well as in monthly devaluation. By using the same unit of time for the devaluation and the interest rates, we ensure that the effect of these trends due to changes in inflation on both volatilities will be fairly symmetric, and will more or less cancel out when the relative volatilities are calculated. The countries for which we did not have data on money market interest rates are: Chile, Greece, Guatemala, Jamaica, New Zealand and Philipines (for which we used deposit rates) and Colombia, Domenican Republic, Israel, Paraguay, Peru and Poland (for which we used lending rates)
} 
aspects: pass-through from exchange rates to prices and extent of foreign currency liabilities.

Authorities may care about the exchange rate in countries in which the passthrough from exchange rates to prices is large, and inflation is an important consideration. Attention to the exchange rate should be smaller in countries where the effects of exchange rate changes on prices is small, or when the passthrough takes a long time to take effect. To study this hypothesis, we develop a rough measure of the pass-through from exchange rates to prices for the countries in our sample. We then use this measure to test whether the countries with high pass-through tend to intervene more in the foreign exchange market, either through reserves or interest rates.

Authorities may also care about the exchange rate in countries in which there are large currency mismatches in the balance sheets of firms, banks, households or the government. If these mismatches are important, depreciations may generate widespread bankruptcies (if the currency mismatches are in the private sector) or result in serious fiscal consequences (if the currency mismatches are in the public sector) or both ${ }^{10}$. This may create incentives for the policymakers to avoid large depreciations. In order to capture the potential for currency mismatches, we will use a variable that captures the ability of countries to borrow abroad in their own currency, and test whether it has an effect on the degree of exchange rate intervention. After considering each of these potential determinants separately, we end the section by discussing their impact when they are both included in the analysis.

\subsection{A simple model of the behavior of the Central Bank}

To set the stage for the empirical analysis, we develop a simple model of the behavior of a Central Bank in response to shocks, in a context in which depreciation leads to inflation, and a portion of debt is denominated in foreign currency. The formal model (based on Aghion et al., 1999) is derived in the appendix; here we just discuss the main building blocks of the model, as well as its implications.

We assume that the Central Bank sets interest rates/exchange rates so as to minimize a standard Barro-Gordon loss function, which depends on inflation and

\footnotetext{
${ }^{10}$ For a discussion of the consequences of devaluation adjustment in the case of foreign currency liabilities see Calvo (1999a and b), Calvo and Reinhart (1999), Hausmann (1999a), Stein et al. (1999), and Fernández-Arias and Talvi (1999).
} 
income. Interest rates and exchange rates are linked through an interest parity condition. Thus, in response to an adverse shock, the Central Bank will either increase domestic interest rates, devalue, or both. In a way, the choice variable of the Central Bank is the policy mix between devaluation and increase in the interest rate.

Prices adjust to changes in the exchange rate, and the magnitude of the adjustment is given by the degree of pass-through. We assume a linear technology with capital as the only factor of production. Thus, output is proportional to the stock of capital. This stock, which fully depreciates each period, is equal to previous period profits (or net wealth), plus debt. We assume that a fixed proportion of debt, $k$, is denominated in foreign currency. Furthermore, firms are credit constrained. They can only borrow an amount proportional to their net wealth, and, following Aghion et al, the coefficient of proportionality depends negatively on the interest rate.

How does the policy response "mix" of the central bank affect the policy objectives, inflation and output? A depreciation affects these objectives through three different channels. First, a depreciation directly affects the rate of inflation. The impact of depreciation on inflation will depend on the level of the passthrough. Second, provided that $k>0$, a depreciation affects output through a balance sheet effect: the depreciation increases the cost of repayment of foreign currency denominated debt, reducing profits in this period, and thus the capital stock and output in the second period. The size of the balance sheet effect will depend on $k$ the share of debt denominated in foreign currency. Third, a larger depreciation entails a smaller increase in interest rates. Thus, a larger depreciation increases output in the second period, since the reduction in interest rates eases the credit constraint (we call this the credit channel effect). The overall effect on income will depend on which of the two channels dominates. If the credit channel dominates over the balance sheet channel, depreciations are expansionary. Otherwise, they are contractionary.

If $k$ and pass through are zero, only the credit channel remains, so the Central Bank will have incentives to respond to a shock by devaluing, without increasing interest rates. The larger $k$ and the associated balance sheet effect), and the larger the rate of pass-through, the larger the incentives for the Central Bank to minimize the movements of the exchange rate and instead respond to external shocks by adjusting the domestic interest rate. An implication of this is that, if the degree of pass-through is high and currency mismatches are important, the interest rate may be used to prevent depreciations, imposing limitations on the ability of the Central Bank to use interest rates exclusively to smooth cyclical fluctuations. Contrary to the standard result according to which nominal shocks require an interest rate adjustment and real shocks an exchange 
rate adjustment, in our model both real and nominal shocks may require interest rate and exchange rate adjustments. As is shown in the Appendix we find that, under both types of shocks, the relative size of the exchange rate / interest rate adjustment will depend on the degree of pass-through and the share of foreign currency liabilities.

In order to test the implications of the model, in what follows we develop measures of exchange rate pass-through and the ability of countries to avoid currency mismatches, and explore whether these variables are associated to the left-hand side variables discussed in Section 2.

\subsection{Exchange rate pass-through and exchange rate management of floaters}

Estimating the exchange rate to price pass-through for a cross-section of countries is not a simple exercise. Ideally, one would want to model each country's price-setting mechanism individually. This would represent a major undertaking, and is out of the scope of this paper. Instead, here we follow a methodology used for Australia by de Brower and Ericsson (1995) and for Mexico by Garcés Diaz (1999). These authors model domestic prices using a mark up equation of the kind:

$$
P=\alpha W^{\theta} F^{\gamma}
$$

Where $P$ are domestic prices, $W$ wages, $F$ international prices in domestic currency (obtained by multiplying the exchange rate with and index of international prices) ${ }^{11}, \alpha$ is the mark up parameter, and $\theta$, and $\gamma$ are the long run elasticities of wages and external prices. By taking the logs of the above equation it is possible to estimate the long-run relationship among wages, international prices, and local prices. Since we do not have monthly data for wages, we estimate the following long-run equation:

$$
p=\log (\alpha)+\gamma f,(2)
$$

where lower case letters represent the log of the variables defined above. While the omission of wages may bias our estimates of pass through, the bias is likely to affect the coefficients of all countries in the same direction. Since our interest is to rank countries according to their pass through, rather than the actual level of the pass-through, the omission of wages should not be too much of a concern. Besides data limitations, there are theoretical reasons for excluding

\footnotetext{
${ }^{11}$ Most of the variation of $F$ is due to exchange rate variation.
} 
wages from the above equation. In particular, if we included wages in Equation (2), the international price coefficient $\gamma$ would not fully capture the impact that the exchange rate may have on prices through its effect on wages. Therefore, Equation (2) is an appropriate specification to estimate what we are interested in, i.e., the total effect of the exchange rate on prices. In any case, it is reassuring that the long run estimates we obtained for Australia and Mexico are very similar to those obtained by de Brower and Ericsson, and by Garcés Díaz ${ }^{12}$.

All the series we use can be described as having a unit root process. Hence, we need to study the long-run relationship between internal and external prices using cointegration analysis. Controlling for the long-run cointegration relationship between exchange rates and prices, we capture the short run dynamics by estimating the following error correction model:

$$
d p_{t}=\phi\left(p_{t-1}+\gamma f_{t-1}+\alpha\right)+\varphi p_{t-1}+\lambda d f_{t-1}+\varepsilon_{t}(3)
$$

We measure $p$ using the log of the CPI. For Germany, the UK, and the nonEuropean countries, we measure $f$ by adding the log of the US dollar exchange rate to the log of an index of international commodity prices (from IFS) ${ }^{13}$. For the rest of the European countries, we measure $f$ by adding the log of the DM exchange rate to the log of the German CPI. Table 2 reports the results of the estimations of 12 months and long run pass-through. The third column of Table 2 shows the number of months required to complete 50 percent of the adjustment toward the new equilibrium. This column shows that the speed of adjustment can differ greatly even for countries with similar levels of pass-trough. In Germany and Paraguay, for instance, a devaluation will have a similar long-run effect on domestic prices, but the adjustment will be much more sluggish in Germany.

While both the long-run and the one-year measures of pass-through can be relevant, the long-run coefficient looses importance if the adjustment is very slow. In Germany, for example, a change in international prices will, in the long run, translate into an equivalent change in domestic prices. However, the adjustment

\footnotetext{
12 Our coefficient for Australia (0.48) is identical to the one obtained by de Brower and Ericsson. The coefficient for Mexico (0.98) is different from the one obtained by Garcés Diaz (0.63) because we use different time periods (1990-99 in this paper and 1985-98 in Garcés Diaz), When we estimate the equation for the 1985-1998 period we obtain a coefficient of 0.69 , very close to the one obtained by Garcés Diaz.

${ }^{13}$ For Canada, Mexico, India, and Peru, we use the log of the US CPI instead of the log of international prices. For the first two countries this choice is due to the important economic links of Canada and Mexico with the USA. In the case of India and Peru, we could not use the index of international prices because the estimations did not converge.
} 
to the steady state requires more than 50 years. In contrast, Greece has a relatively low long-run pass through (0.23) but a very fast adjustment. If we compare the two countries we find that, for almost three years, a change in external prices has a stronger effect on Greek domestic prices than on German prices. For this reason, in the empirical analysis below we use the one-year pass through as the relevant explanatory variable . $^{14}$

Figures 1, 2 and 3 show the relationship between one-year pass-through and the three measures of foreign exchange intervention discussed in Section 2. Figure 1 shows a positive (but not statistically significant) correlation between the level of reserves and pass-through. The correlation coefficient is 0.26 . Notice that Singapore has both extremely high reserves and low pass-through. If we drop this outlier, the correlation coefficient jumps to 0.52 , and becomes highly significant. The figure suggests that while countries with low pass-through may choose to have whatever levels of reserve they want, countries with high passthrough find it necessary to build war chests of international reserves in order to be able to defend their exchange rate.

Figures 2 and 3 show instead a negative correlation between pass-through and the relative volatility of exchange rate vis a vis reserves and interest rates. The correlation coefficients are -0.44 and -0.37 respectively, and are in both cases statistically significant. All in all, through this simple univariate analysis, we find that exchange rate pass-through does have a role in explaining the degree to which policymakers intervene in foreign exchange markets, a result that is consistent with the model outlined in Section 3.1. As we will see in Section 3.4, however, the impact of pass-through becomes more limited once we account for the role of foreign currency liabilities.

\footnotetext{
${ }^{14}$ However, we check that our results are robust to the use of alternative measures of pass-through which combine the short and long run into a single indicator, or to the use of proxies such as the degree of openness.
} 
Table 2. Estimates of Inflation pass-through (1990-99)

\begin{tabular}{lccc}
\hline & $\begin{array}{c}\text { 12 months } \\
\text { pass-through }\end{array}$ & $\begin{array}{c}\text { Long-run pass- } \\
\text { through }\end{array}$ & $\begin{array}{c}\text { Half-life of adjustment } \\
\text { (number of months) }\end{array}$ \\
\hline Australia & 0.21 & 0.48 & 14 \\
Canada & 0.07 & 0.19 & 16 \\
Colombia (1992-99) & 0.38 & 1.58 & 30 \\
Czech Republic & 0.02 & 1.17 & 240 \\
Dominican Republic & 0.25 & 1.38 & 32 \\
Germany & 0.07 & 0.97 & 130 \\
Greece & 0.15 & 0.23 & 1 \\
Guatemala & 0.28 & 0.86 & 20 \\
India & 0.07 & 0.92 & 220 \\
Indonesia & 0.49 & 0.92 & 11 \\
Israel & 0.16 & 0.55 & 30 \\
Jamaica & 0.31 & 0.41 & 2 \\
Japan & 0.04 & 0.09 & 17 \\
Korea & 0.18 & 0.59 & 10 \\
Mexico & 0.58 & 0.93 & 26 \\
Norway (1988-99) & 0.09 & 0.32 & 10 \\
Paraguay & 0.59 & 0.98 & 12 \\
Peru (1992-99) & 0.22 & 0.43 & 26 \\
Philippines & 0.30 & 1.16 & 1 \\
Poland & 0.62 & 0.80 & 50 \\
Singapore & 0.02 & 0.16 & 35 \\
South Africa & 0.11 & 0.47 & 1 \\
Sweden & 0.14 & 0.22 & 50 \\
Switzerland & 0.02 & 0.02 & 12 \\
Thailand & 0.03 & 0.19 & 56 \\
UK & 0.03 & 0.06 & \\
USA* & 0.04 & 0.34 & \\
\hline Nind & & & 5 \\
\hline
\end{tabular}

*International prices versus US effective nominal rate

\subsection{Currency mismatches and exchange rate management of floaters}

In order to test the importance of currency mismatches for exchange rate management, we develop a set of indicators that measure the ability of countries to borrow internationally in their own currency. We believe that the inability of countries to borrow in their own currency is a fundamental determinant of the existence of currency mismatches in the country's balance sheets, since it is this inability that makes it more difficult for agents to hedge their currency risks. For this purpose, we rely on two different databases from the Bank of International Settlements (BIS). One of them records international transactions involving the banking sector, while the other one reports international debt securities transactions (including bonds and money market instruments). 
Our first indicator of the ability of a country to borrow internationally in its own currency is based on the international debt securities database, which contains data on debt instruments dissagregated by nationality of issuer and by currency. Our index measures the ratio between the stock of international debt securities issued by a country in its own currency and the total stock of securities issued by the country in all currencies. Table 3 presents the value of this indicator (which we call ABILITY1) for all the countries in our sample. The figures correspond to the 1998-1999 average. Notice that this ratio is 0 in almost half of the countries, and is very small (lower than $3 \%$ ) in more than two thirds of the cases. The bottom part of the table shows that there is a very high correlation between this indicator and the level of development. In fact, South Africa is the only developing country with a significant amount of debt securities denominated in their own currency.

Table 3: Ability to borrow in own currency

\begin{tabular}{|c|c|c|c|}
\hline & Ability1 & Ability2 & Ability3 \\
\hline Australia & 0.214 & 0.247 & 0.437 \\
\hline Brazil & 0.000 & 0.051 & 0.000 \\
\hline Canada & 0.152 & 0.172 & 0.273 \\
\hline Chile & 0.000 & 0.029 & 0.000 \\
\hline Colombia & 0.000 & 0.000 & 0.000 \\
\hline Czech Republic & 0.000 & 0.244 & 0.000 \\
\hline Dominican Republic & 0.000 & 0.020 & 0.000 \\
\hline Germany & 0.279 & 0.463 & 0.872 \\
\hline Greece & 0.028 & 0.154 & 0.245 \\
\hline Guatemala & 0.000 & 0.004 & 0.000 \\
\hline India & 0.000 & 0.040 & 0.000 \\
\hline Indonesia & 0.010 & 0.054 & 0.000 \\
\hline Israel & 0.000 & 0.020 & 0.000 \\
\hline Jamaica & 0.000 & 0.011 & 0.000 \\
\hline Japan & 0.513 & 0.492 & 1.522 \\
\hline Korea South & 0.000 & 0.011 & 0.000 \\
\hline Mexico & 0.001 & 0.011 & 0.000 \\
\hline New Zealand & 0.041 & 0.144 & 1.048 \\
\hline Norway & 0.006 & 0.125 & 0.053 \\
\hline Paraguay & 0.000 & 0.000 & 0.000 \\
\hline Peru & 0.000 & 0.046 & 0.000 \\
\hline Philippines & 0.007 & 0.035 & 0.019 \\
\hline Poland & 0.022 & 0.151 & 0.324 \\
\hline Singapore & 0.007 & 0.030 & 0.000 \\
\hline South Africa & 0.112 & 0.229 & 1.173 \\
\hline Sweden & 0.021 & 0.208 & 0.076 \\
\hline Switzerland & 0.164 & 0.271 & 2.055 \\
\hline Thailand & 0.022 & 0.020 & 0.000 \\
\hline United Kingdom & 0.467 & 0.191 & 0.943 \\
\hline United States & 0.782 & 0.796 & 2.325 \\
\hline
\end{tabular}


Regional Average

\begin{tabular}{lccc}
\hline & Ability1 & Ability2 & Ability3 \\
\hline G3 & 0.520 & 0.580 & 1.570 \\
Other Industrialized & 0.120 & 0.170 & 0.570 \\
Emerging Countries & 0.014 & 0.070 & 0.130 \\
Other Developing & 0.000 & 0.020 & 0.000 \\
Lac Emerging & 0.000 & 0.030 & 0.000 \\
East Asia & 0.010 & 0.030 & 0.000 \\
All Countries & 0.108 & 0.152 & 0.443 \\
\hline
\end{tabular}

A drawback of our first indicator is that it only captures one third of the total claims registered by the BIS. To address the limited coverage of this indicator, we compute a second indicator (ABILITY2) using, together with the data on debt securities included in ABILITY1, BIS data on total claims of the banking sector. Unfortunately, BIS does not provide the complete currency breakdown of the claims of the banking sector. The data are only available for 10 currencies (six of which correspond to countries in our sample) plus an "other currencies" category. ${ }^{15}$ For the remaining 24 countries for which we do not have information, all bank debt in "other currencies" was assumed to be denominated in a country's own currency. Thus, this indicator overestimates the ability of countries to borrow abroad in own currency. Although we sacrifice precision, the gains in terms of coverage are important. In fact, the debt considered represents on average more than $60 \%$ of the total foreign debt of the countries in the sample. The value of ABILITY2 for each country, as well as the averages for groups of countries, is presented in the second column of Table 3.

Our third indicator relies, as the first one, on the debt securities database. In this case, we compute the ratio between the stock of foreign securities issued in a given currency (regardless of the nationality of the issuer) and the amount of foreign securities issued by the corresponding country. The results are presented in the third column of Table 3. Notice that several developed countries have values greater than one. This indicates that other countries issue securities in those currencies. Not surprisingly, the value corresponding to the United States is the largest. In fact, by comparing the values of our first and third indicators, it is easy to see that about two thirds of the total stock of dollar debt instruments has

15 The currency breakdown is available for Belgian Francs, Swiss Francs, Deutsche Marks, ECUs, French Francs, British Pounds, Italian Liras, Japanese Yens, Netherlands Guilders, and US Dollars. It is striking that these 10 currencies account for $94 \%$ of the total international bank transactions around the world, a clear indication of the limited use of "other currencies" in these transactions. Even if we excluded the countries that issue these currencies, debts denominated in "other currencies" only account for $9 \%$ of the total international bank debt of other countries. 
been issued by countries other than the United States. More surprising is the fact that South Africa has a value greater than unity, suggesting that its currency is widely used by nationals of other countries.

Although this indicator may seem less precise than the other two, we think that it is a good measure of the potential for foreign currency mismatches. The difficulty in hedging foreign currency risk is the need to find agents willing to take the other side of the transaction. To hedge foreign currency risk is equivalent to borrow in own currency since, from the point of view of the borrower, a debt in domestic currency is equivalent to a dollar debt plus a hedge. If a country is unable to borrow in its own currency, then it will be unable to hedge its currency risk. However, if a non-resident is able to borrow in this country's currency (for example, South African Rand), then he may be able to swap his Rand obligations for dollar obligations of a South African resident, thus providing the basis for a hedge. This suggests that what is critical is the overall balance between total debt issued by a country, and the total debt issued in its currency. If these amounts are balanced, then the swap market can extinguish any remaining currency mismatches. Thus, by including in the numerator all debt securities issued in the country's currency, this indicator may be more appropriate than the others as a measure of the potential problems that could arise due to currency mismatches. It is worth noting, in any case, that the correlation between our three indices is extremely high, larger than 0.8 in all cases, so results are not sensitive to the index used.

It could be argued that the effects of the ability to borrow abroad in own currency on the left-hand side variables identified in Section 2 may be non-linear. The important difference may be whether a country can or cannot borrow abroad in own currency; differences between countries such as Germany and the United States may be less important. This suggests the use of a fourth indicator, ABILITY4, which is a dummy variable that takes a value of one if the country can borrow abroad in own currency, zero otherwise. We built this variable by assigning a value of 1 to countries for which our ABILITY1 index was greater than $0.1^{16}$.

Figures 4, 5 and 6 present the relationship between our second index and the three measures discussed in Section 2: the level of reserves, the relative volatility of exchange rates and reserves, and the relative volatility of exchange rates and interest rates. Figure 4 shows a very strong negative association between the ability of a country to borrow in its own currency and the stock of international reserves. The correlation between the two variables is -0.5 , and it is

${ }^{16}$ Results reported in next section are robust to different definitions of this dummy. 
significant at the 1 percent level. The figure suggests that countries that are unable to borrow in their own currency find it necessary to keep large stock of reserves in order to defend their currency.

Figure 5 shows the relationship between the ability to borrow in domestic currency and the relative volatility of exchange rates and reserves. The relationship is positive and quite strong. The correlation is 0.6 , and significant at the 1 percent level. Results are fairly similar when we consider intervention using interest rates instead of reserves (Figure 18). In this case, the correlation is 0.7 , and highly significant.

In sum, our results suggest that the ability to borrow in domestic currency is an important determinant of the degree to which policymakers are able to show what has been called "benign neglect" regarding the behavior of the exchange rate. Central Banks of countries unable to borrow in their own currencies will internalize the potential negative impact of a depreciation due to currency mismatches when carrying out exchange rate and monetary policy.

\subsection{The impact of pass through and foreign currency mismatches on exchange rate management}

The previous sections focused on the role of the exchange rate pass-through and that of foreign currency liabilities when considered independently. Here we bring them together into the analysis of the differences in behavior among floaters. We run a large set of regressions where we explain the level of reserves, as well as the relative volatility of exchange rates vis a vis reserves and interest rates using as explanatory variables the degree of exchange rate passthrough and our indices of ability to borrow in own currency. In addition to these, we consider two other explanatory variables. First, in order to check whether our results are driven by the level of economic development, we augment the regressions with a measure of GDP per capita ${ }^{17}$. Second, to control for the fact that countries may need time to "learn" how to operate under a flexible exchange rate, we include in our regressions a measure of the number of months since the country started floating (in logs). By using our four different indices of the ability to borrow in own currencies and the set of explanatory variables described above, we obtain 16 different specifications for each of our three dependent variables. The results of the regressions are reported in Tables 4, 5, and 6.

\footnotetext{
17 Alternatively, we also tried an industrialized country dummy, which produced similar results.
} 
Table 4 presents the results of the regressions for the level of international reserves. We find that the ability to borrow in own currency is negatively associated with the level of reserves, and highly significant in every one of the regressions. The effect is quite substantial. In the regressions using our first index, for example, a one standard deviation increase in the ability to borrow in own currency is associated to a 10 percentage point decrease in international reserves. We find that the exchange rate pass-through coefficient almost always has a positive (but not statistically significant) sign. Our control variables, GDP per capita and "experience" in floating do not play any role in explaining the level of reserves.

Tables 5 and 6 show the ability to borrow in own currency is strongly associated with the relative volatility of devaluation vis a vis reserves and interest rates. ${ }^{18}$ The results are extremely robust, the coefficient is positive and statistically significant in all regressions, significant at 5 percent confidence level in 30 out of 32 regressions, and at 1 percent confidence level in 22 out of 32 regressions. In the regression using our first index a one-standard deviation increase in the ability to borrow in own currency is associated with an increase in the volatility of devaluation vis a vis reserves of 1 (which corresponds to about three quarters of one-standard deviation of the relative volatility of devaluations vis a vis reserves) and to an increase in the volatility of devaluation vis a vis interest rate of 0.55 (which corresponds to about half of one-standard deviation of the relative volatility of devaluations vis a vis interest rate). The coefficient attached to pass-through has in most cases the expected negative sign, but is rarely significant. If anything, pass-through has a marginal effect on the relative volatility of exchange rate vis a vis international reserves. Income per capita does not play any role in explaining the relative volatility of devaluations and international reserves but it is often positively correlated with the relative volatility of devaluations and interest rate. Finally, the number of months since the country has started floating does not seem to play any role in explaining the relative volatility of devaluations.

We also ran a series of robustness tests, using other two definitions of ability to borrow in own currency (total loans and total claims), different measures of pass-through (long-run pass-through, a weighted average of long and short run pass through in which the weight of the long run measure depends on the speed of adjustment, an alternative measure of pass-through computed using an OLS regression of changes in prices over changes in exchange rate, and openness as a proxy of pass-through), and dummies to capture the non-linearities in the

${ }^{18}$ In the regressions we use the log of the volatility of devaluation. The results are robust to using the levels. 
behavior of G3 countries. In order to check whether our results are driven by outliers, we also re-ran all our regressions using a robust estimator and we did not find any significant difference with respect to the results illustrated in Tables 4 through $6^{19}$. The only significant change is that, when we control for outliers, pass-through becomes a significant factor in explaining the level of international reserves.

The results of Tables 4 through 6 are surprisingly strong: we ran a very large set of regression and we found that ability to borrow in own currency is always highly correlated with our measures of how countries float. To make sure that our results were not driven by mistakes or arbitrariness in our definition of how countries float, we now use, as a dependent variable, the de facto classification of exchange rate regimes computed by Levy Yeyati and Sturzenegger (1999). These authors observe that not all countries float (or fix) in the same way. Some, officially, floating countries have levels of intervention in the foreign exchange market that make them indistinguishable from countries with a fixed exchange rate. In order to differentiate "Deeds vs Words", Levy Yeyati and Sturzenegger (1999) use cluster analysis to classify countries into four different groups (Flexible, Dirty Float, Crawling Peg, Fixed) independent of the official regime stated by the country that is assigned to the group.

For 27 countries, our sample overlaps with Levy Yeyati and Sturzenegger's sample. We use their data for 1997 and generate a new index (LY\&S) that takes a value of one for countries that are classified as having a floating exchange rate, two for countries that are classified as dirty float, three for crawling pegs, and four for countries classified as fixed (the data are reported in the last column of Table A2). The index is hence inversely correlated to a country's willingness to float its exchange rate. As expected, we find that LY\&S is positively correlated with the average level of international reserves and negatively correlated with intervention in foreign markets, we were instead somewhat surprised to find that these correlations were not statistically significant.

As the LY\&S index provides a discrete measure, rather than a continuous one, of the willingness to float, the appropriate method to study its correlation with pass-through and the ability to borrow in own currency would be an ordered probit model. Unfortunately, this methodology requires a rather large sample and it is not appropriate for our small sample of 27 countries. To gain some insight, we study the correlation between the LY\&S index, pass-through and the ability to borrow in own currency using OLS. The results are reported in Table 7. As

19 The estimator used is the one suggested by STATA. The results of the robust estimations, as well as the details of the estimation procedure are available upon request. 
before, we find that the ability to borrow in own currency is positively and significantly correlated with the willingness to float. Surprisingly, we also find that the degree of pass-through is positively correlated to the willingness to float index, although this relationship is never statistically significant.

\section{CONCLUSIONS}

There are significant differences in the behavior of countries that have adopted floating exchange rate systems (or very wide bands). We document these differences by showing that these countries hold very different levels of reserves and allow very different degrees of flexibility of the exchange rate relative to the volatility of their reserves or of the interest rate. In general, G-3 countries float with a very low level of reserves and with a high volatility of the exchange rate relative to that of the level of reserves or of the interest rate. Emerging countries are at the opposite extreme, while other industrial countries are in an intermediate position.

We present a model that interprets these differences as the optimal response of a Central Bank that minimizes a loss function in inflation and output in a context in which firms are subject to credit constraints and currency mismatches. The model focuses on the fact that countries differ in their ability to deal with the currency mismatch problem and have different levels of pass-through from exchange rates to prices. The model finds that, in countries with large currency mismatches and high levels of exchange rate pass-through, the Central Bank will be more concerned about the level of the exchange rate and hence limit exchange rate volatility.

We explore the implications of the model in a sample of developing and industrial countries with floating regimes (or wide bands). We find a very strong and robust relationship between the ability of a country to borrow internationally in its own currency and the way it manages its exchange rate system. In particular, we conclude that floating rate countries that do not to borrow internationally in their own currency tend to hold significantly larger reserve levels, and to allow much less volatility in the exchange rate relative to their interventions with international reserves and interest rate. We find weaker and less robust results with respect to the effects of passthrough. 
Table 4: Average level of international reserves

\begin{tabular}{|c|c|c|c|c|c|c|c|}
\hline \multicolumn{8}{|c|}{ Dependent Variable: Average level of international reserves } \\
\hline \multirow[b]{2}{*}{$\begin{array}{l}\text { Index } \\
\text { used in the } \\
\text { regression }\end{array}$} & \multicolumn{7}{|c|}{ Explanatory variables } \\
\hline & $\begin{array}{l}\text { Liabilities in } \\
\text { Currency }\end{array}$ & own & Pass Through & $\begin{array}{l}\text { GDP } \\
\text { per capita }\end{array}$ & $\begin{array}{l}\text { Months } \\
\text { since floating }\end{array}$ & $R^{2}$ & N. Obs \\
\hline \multirow[t]{2}{*}{ Ability1 } & -0.507 & $* \star *$ & 0.060 & & & 0.28 & 27 \\
\hline & $(0.179)$ & & $(0.212)$ & & & & \\
\hline \multirow[t]{2}{*}{ Ability1 } & -0.585 & ** & 0.139 & 0.030 & & 0.31 & 27 \\
\hline & $(0.245)$ & & $(0.154)$ & $(0.035)$ & & & \\
\hline \multirow[t]{2}{*}{ Ability1 } & -0.567 & * & 0.117 & 0.031 & -0.010 & 0.31 & 27 \\
\hline & $(0.278)$ & & $(0.125)$ & $(0.035)$ & $(0.022)$ & & \\
\hline \multirow[t]{2}{*}{ Ability1 } & -0.555 & ** & & 0.016 & -0.011 & 0.27 & 30 \\
\hline & $(0.251)$ & & & $(0.035)$ & $(0.022)$ & & \\
\hline \multirow[t]{2}{*}{ Ability2 } & -0.477 & $* *$ & 0.063 & & & 0.24 & 27 \\
\hline & $(0.208)$ & & $(0.247)$ & & & & \\
\hline \multirow[t]{2}{*}{ Ability2 } & -0.572 & * & 0.136 & 0.031 & & 0.26 & 27 \\
\hline & $(0.293)$ & & $(0.193)$ & $(0.038)$ & & & \\
\hline \multirow[t]{2}{*}{ Ability2 } & -0.548 & & 0.097 & 0.033 & -0.017 & 0.27 & 27 \\
\hline & $(0.324)$ & & (0.168) & $(0.037)$ & $(0.021)$ & & \\
\hline \multirow[t]{2}{*}{ Ability2 } & -0.563 & * & & 0.022 & -0.016 & 0.25 & 30 \\
\hline & $(0.292)$ & & & $(0.0380$ & $(0.022)$ & & \\
\hline \multirow[t]{2}{*}{ Ability3 } & -0.143 & $\star \star \star *$ & 0.068 & & & 0.26 & 27 \\
\hline & $(0.053)$ & & $(0.225)$ & & & & \\
\hline \multirow[t]{2}{*}{ Ability3 } & -0.162 & $\star \star$ & 0.138 & 0.026 & & 0.28 & 27 \\
\hline & $(0.069)$ & & $(0.171)$ & $(0.035)$ & & & \\
\hline \multirow[t]{2}{*}{ Ability3 } & -0.156 & * & 0.113 & 0.027 & -0.011 & 0.29 & 27 \\
\hline & $(0.080)$ & & $(0.142)$ & $(0.034)$ & $(0.022)$ & & \\
\hline \multirow[t]{2}{*}{ Ability3 } & -0.172 & $* *$ & & 0.020 & -0.009 & 0.30 & 30 \\
\hline & $(0.074)$ & & & $(0.036)$ & $(0.024)$ & & \\
\hline \multirow[t]{2}{*}{ Ability4 } & -0.270 & $\star \star \star *$ & -0.033 & & & 0.39 & 27 \\
\hline & $(0.078)$ & & $(0.222)$ & & & & \\
\hline \multirow[t]{2}{*}{ Ability4 } & -0.318 & $* * *$ & 0.068 & 0.042 & & 0.44 & 27 \\
\hline & $(0.108)$ & & (0.151) & $(0.036)$ & & & \\
\hline \multirow[t]{2}{*}{ Ability4 } & -0.326 & $* *$ & 0.082 & 0.042 & 0.007 & 0.44 & 27 \\
\hline & (0.129) & & $(0.130)$ & (0.036) & $(0.028)$ & & \\
\hline Ability4 & $\begin{array}{l}-0.298 \\
(0.114)\end{array}$ & ** & & $\begin{array}{c}0.025 \\
(0.036)\end{array}$ & $\begin{array}{c}0.003 \\
(0.026)\end{array}$ & 0.37 & 30 \\
\hline
\end{tabular}


Why do countries float the way...

Table 5: Depreciations and volatility of international reserves

\begin{tabular}{|c|c|c|c|c|c|c|c|c|}
\hline \multicolumn{9}{|c|}{ Dependent Variable: Relative volatility of depreciation and international reserves } \\
\hline \multirow[b]{2}{*}{$\begin{array}{l}\text { Index } \\
\text { used in the } \\
\text { regression }\end{array}$} & \multicolumn{8}{|c|}{ Explanatory variables } \\
\hline & $\begin{array}{l}\text { Liabilities in } \\
\text { own } \\
\text { Currency }\end{array}$ & \multicolumn{3}{|c|}{ Pass Through } & $\begin{array}{l}\text { GDP } \\
\text { per capita }\end{array}$ & $\begin{array}{l}\text { Months } \\
\text { since } \\
\text { floating }\end{array}$ & $R^{2}$ & N. Obs \\
\hline Ability1 & $\begin{array}{c}4.900 \\
(0.993)\end{array}$ & *** & $\begin{array}{l}-0.955 \\
(0.780)\end{array}$ & & & & 0.67 & 27 \\
\hline \multirow[t]{2}{*}{ Ability1 } & 5.447 & *** & -1.508 & * & -0.212 & & 0.70 & 27 \\
\hline & $(1.138)$ & & $(0.805)$ & & $(0.134)$ & & & \\
\hline \multirow[t]{2}{*}{ Ability1 } & 5.653 & 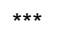 & -1.765 & * & -0.203 & -0.114 & 0.71 & 27 \\
\hline & (1.237) & & $(0.877)$ & & $(0.129)$ & $(0.108)$ & & \\
\hline \multirow[t]{2}{*}{ Ability1 } & 5.415 & $\star \star \star *$ & & & -0.018 & -0.078 & 0.55 & 30 \\
\hline & $(1.270)$ & & & & $(0.140)$ & $(0.1120)$ & & \\
\hline \multirow[t]{2}{*}{ Ability2 } & 3.775 & 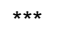 & -1.353 & & & & 0.45 & 27 \\
\hline & (0.941) & & (1.062) & & & & & \\
\hline \multirow[t]{2}{*}{ Ability2 } & 4.219 & $\star \star *$ & -1.694 & & -0.145 & & 0.46 & 27 \\
\hline & $(0.984)$ & & (1.085) & & $(0.166)$ & & & \\
\hline \multirow[t]{2}{*}{ Ability2 } & 4.236 & 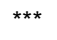 & -1.722 & & -0.144 & -0.012 & 0.46 & 27 \\
\hline & (1.034) & & (1.229) & & $(0.166)$ & $(0.135)$ & & \\
\hline \multirow[t]{2}{*}{ Ability2 } & 4.317 & 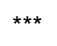 & & & 0.013 & 0.001 & 0.37 & 30 \\
\hline & (1.031) & & & & $(0.160)$ & $(0.124)$ & & \\
\hline \multirow[t]{2}{*}{ Ability3 } & 1.071 & 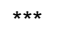 & -1.479 & & & & 0.46 & 27 \\
\hline & $(0.355)$ & & $(0.890)$ & & & & & \\
\hline \multirow[t]{2}{*}{ Ability3 } & 1.143 & $* \star *$ & -1.742 & * & -0.099 & & 0.47 & 27 \\
\hline & $(0.366)$ & & $(0.923)$ & & (0.158) & & & \\
\hline \multirow[t]{2}{*}{ Ability3 } & 1.170 & $\star \star \star *$ & -1.859 & * & -0.095 & -0.052 & 0.47 & 27 \\
\hline & (0.394) & & $(1.027)$ & & $(0.158)$ & $(0.118)$ & & \\
\hline \multirow[t]{2}{*}{ Ability3 } & 1.323 & $\star * \star$ & & & 0.026 & -0.053 & 0.43 & 30 \\
\hline & (0.388) & & & & $(0.138)$ & $(0.122)$ & & \\
\hline \multirow[t]{2}{*}{ Ability4 } & 1.859 & $\star \star \star *$ & -0.909 & & & & 0.57 & 27 \\
\hline & $(0.443)$ & & $(0.859)$ & & & & & \\
\hline \multirow[t]{2}{*}{ Ability4 } & 2.071 & $\star * * *$ & -1.345 & & -0.183 & & 0.59 & 27 \\
\hline & $(0.471)$ & & $(0.869)$ & & $(0.151)$ & & & \\
\hline \multirow[t]{2}{*}{ Ability4 } & 2.254 & $* \star *$ & -1.676 & * & -0.179 & -0.168 & 0.61 & 27 \\
\hline & $(0.489)$ & & $(0.923)$ & & $(0.147)$ & $(0.124)$ & & \\
\hline Ability4 & $\begin{array}{c}2.014 \\
(0.582)\end{array}$ & $\star \star \star *$ & & & $\begin{array}{c}0.026 \\
(0.170)\end{array}$ & $\begin{array}{l}-0.110 \\
(0.127)\end{array}$ & 0.44 & 30 \\
\hline
\end{tabular}


Table 6: Depreciations and exchange rate volatility

\begin{tabular}{|c|c|c|c|c|c|c|c|c|}
\hline \multicolumn{9}{|c|}{ Dependent Variable: Relative volatility of depreciation and interest rate } \\
\hline \multirow[b]{2}{*}{$\begin{array}{l}\text { Index } \\
\text { used in the } \\
\text { regression }\end{array}$} & \multicolumn{8}{|c|}{ Explanatory variables } \\
\hline & $\begin{array}{l}\text { Liabilities in own } \\
\text { Currency }\end{array}$ & \multicolumn{2}{|r|}{ Pass Through } & \multicolumn{2}{|c|}{$\begin{array}{l}\text { GDP } \\
\text { per capita }\end{array}$} & $\begin{array}{l}\text { Months } \\
\text { since } \\
\text { floating }\end{array}$ & $R^{2}$ & N. Obs \\
\hline \multirow[t]{2}{*}{ Ability1 } & 3.379 & ** & -0.698 & & & & 0.46 & 27 \\
\hline & $(1.269)$ & & $(0.630)$ & & & & & \\
\hline \multirow[t]{2}{*}{ Ability1 } & 2.598 & ** & 0.091 & 0.302 & ** & & 0.55 & 27 \\
\hline & $(1.189)$ & & $(0.672)$ & $(0.143)$ & & & & \\
\hline \multirow[t]{2}{*}{ Ability1 } & 2.523 & * & 0.185 & 0.299 & * & 0.042 & 0.55 & 27 \\
\hline & (1.238) & & $(0.710)$ & $(0.151)$ & & $(0.087)$ & & \\
\hline \multirow[t]{2}{*}{ Ability1 } & 2.604 & ** & & 0.283 & * & 0.039 & 0.55 & 30 \\
\hline & (1.193) & & & $(0.140)$ & & $(0.075)$ & & \\
\hline \multirow[t]{2}{*}{ Ability2 } & 3.822 & $\star \star \star ~$ & -0.433 & & & & 0.50 & 27 \\
\hline & $(1.410)$ & & $(0.646)$ & & & & & \\
\hline \multirow[t]{2}{*}{ Ability2 } & 3.009 & ** & 0.192 & 0.266 & * & & 0.57 & 27 \\
\hline & (1.330) & & $(0.711)$ & $(0.145)$ & & & & \\
\hline \multirow[t]{2}{*}{ Ability2 } & 2.920 & ** & 0.339 & 0.259 & & 0.064 & 0.57 & 27 \\
\hline & (1.367) & & $(0.767)$ & $(0.154)$ & & $(0.085)$ & & \\
\hline \multirow[t]{2}{*}{ Ability2 } & 3.005 & ** & & 0.232 & & 0.051 & 0.57 & 30 \\
\hline & (1.324) & & & $(0.144)$ & & $(0.074)$ & & \\
\hline \multirow[t]{2}{*}{ Ability3 } & 0.864 & $\star \star \star *$ & -0.879 & & & & 0.38 & 27 \\
\hline & $(0.307)$ & & $(0.616)$ & & & & & \\
\hline \multirow[t]{2}{*}{ Ability3 } & 0.584 & * & 0.166 & 0.335 & ** & 0.062 & 0.50 & 27 \\
\hline & $(0.298)$ & & $(0.725)$ & $(0.153)$ & & $(0.088)$ & & \\
\hline \multirow[t]{2}{*}{ Ability3 } & 0.616 & ** & 0.026 & 0.341 & $\star *$ & & 0.49 & 27 \\
\hline & $(0.283)$ & & (0.669) & (0.145) & & & & \\
\hline \multirow[t]{2}{*}{ Ability3 } & 0.577 & ** & & 0.317 & ** & 0.059 & 0.49 & 30 \\
\hline & $(0.271)$ & & & $(0.144)$ & & $(0.075)$ & & \\
\hline \multirow[t]{2}{*}{ Ability4 } & 1.446 & $* \star *$ & -0.481 & & & & 0.46 & 27 \\
\hline & $(0.400)$ & & $(0.642)$ & & & & & \\
\hline \multirow[t]{2}{*}{ Ability 4} & 1.099 & $* \star *$ & 0.231 & 0.298 & ** & & 0.54 & 27 \\
\hline & $(0.362)$ & & (0.648) & $(0.142)$ & & & & \\
\hline \multirow[t]{2}{*}{ Ability4 } & 1.090 & $\star \star \star *$ & 0.247 & 0.298 & * & 0.008 & 0.54 & 27 \\
\hline & $(0.392)$ & & $(0.672)$ & $(0.147)$ & & (0.098) & & \\
\hline Ability4 & $\begin{array}{l}1.102 \\
(0.364)\end{array}$ & $\star \star \star ~$ & & $\begin{array}{c}0.284 \\
(0.139)\end{array}$ & ** & $\begin{array}{c}0.008 \\
(0.081)\end{array}$ & 0.54 & 30 \\
\hline
\end{tabular}


Table 7: True Versus False Floaters

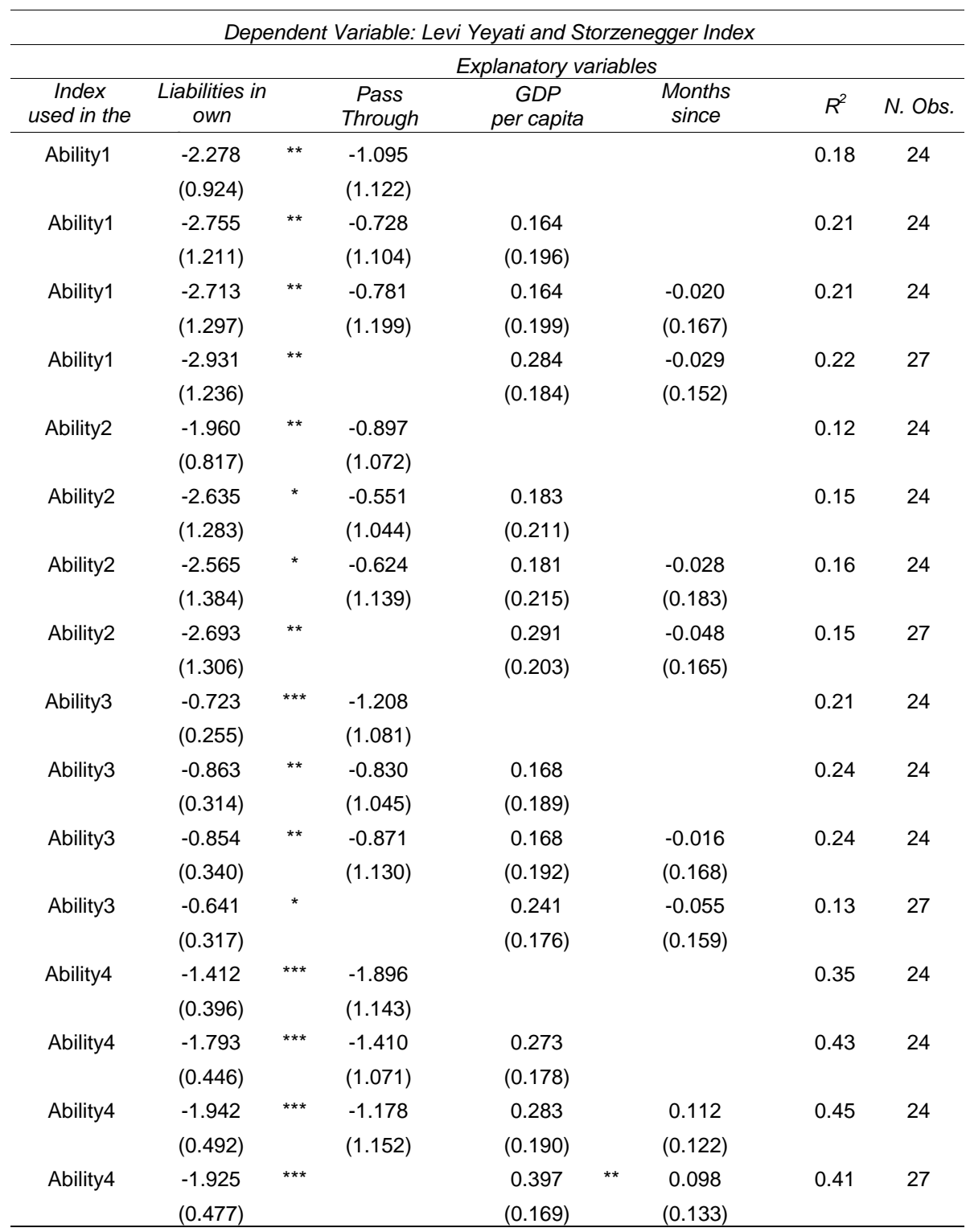


APPENDIXZ

EXCHANGE RATE OR INTEREST RATE ADJUSTMENT. A SIMPLE MODEL

In this Appendix, we follow Aghion et al. (2000) and Bacchetta (2000) and present a simple model studying how the structure of the economy affects the Central Bank's response to external shocks. In particular, we look at the choice between adjusting the interest rate and the exchange rate and show that passthrough and the presence of dollar denominated liabilities are relevant for this choice. We show that in countries with high pass-through and high dollarization the Central Bank is more likely to use the interest rate and that in countries with low pass-through and low dollarization the Central Bank is more likely to use the exchange rate. We start by describing the basic structure of the economy and the preferences of the Central Bank and then, we discuss what is the Central Bank's optimal reaction to real and nominal shocks.

\section{PRODUCTION}

We assume a linear technology of the kind $Y_{t}=\sigma_{t} K_{t}$. Capital stock fully depreciates and, at the beginning of period $t$, capital is equal to net wealth $W_{t}$ plus debt $D_{t}$ (hence, $K_{t}=W_{t}+D_{t}$ ). As in Aghion et al. (2000), we assume that, because of credit constraints, entrepreneurs can only borrow an amount $\mu W_{t}$ proportional to their net wealth. Aghion et al. (1999) use moral hazard considerations to formally derive $\mu$ and show that this credit multiplier has an inverse relationship with the interest rate of the previous period. In particular, we can write total debt in period $t$ as: $D_{t=} \mu\left(i_{t-1}\right) W_{t}$, with $\mu^{\prime}<0$, and $\mu^{\prime}>0$. (Aghion et al, 1999, use the real interest rate, we follow Bacchetta, 2000, and use the nominal interest rate)

We also assume that firms are not able to raise all the capital they need in domestic currency and that a fraction $\kappa$ of their debt is in foreign currency. While Aghion et al. (2000) endogenize $\kappa$, we will assume that the ability to borrow in domestic currency is exogenous and that it is related to what Hausmann (1999) calls the original sin of emerging markets. We can then write production as a function of current wealth:

$$
Y_{t}=\sigma_{t}\left(1+\mu\left(i_{t-1}\right)\right) W_{t}
$$

If no profits are distributed, current wealth is equal to the real value of profits in the previous period. Or, $W_{t+1}=\Pi_{t} / P_{t}$. Since capital is the only factor of 
production, profits are given by the value of the output minus debt repayments. Hence, real profits are given by:

$$
\frac{\Pi_{t}}{P_{t}}=Y_{t}-D_{t}\left[\left(1+i_{t-1}\right)(1-\kappa)+\left(1+i_{t-1}^{*}\right) \kappa \frac{e_{t}}{e_{t-1}}\right]
$$

Where $i_{t-1}$ is the interest rate in period $t-1$ (we would obtain exactly the same results by using $i_{t}$ instead of $i_{t-1}$ ), paid on domestic currency debt, $1-\kappa$ is the share of domestic currency debt, $i^{\star}$ is the interest rate paid on foreign currency debt, and $\kappa$ the share of debt in foreign currency. By setting $S_{t}\left(i_{t-1}\right)=\sigma\left(1-\mu\left(i_{t-1}\right)\right)$ (with $S^{\prime}<0$ and $S^{\prime \prime}>0$ ) we can write the following expression for income in period $t$ :

$$
Y_{t}=S_{t}\left(i_{t-1}\right)\left[Y_{t-1}-D_{t-1}\left[\left(1+i_{t-2}\right)(1-\kappa)+\left(1+i^{*}\right) \kappa \frac{e_{t-1}}{e_{t-2}}\right]\right]
$$

\section{PRICES AND INTEREST RATE}

We assume that in equilibrium PPP holds, but prices are sticky and are a function of changes of the exchange rate in the previous period. Following a devaluation in period $t-1$, prices in period $t$ (devaluation happens after prices in period $t-1$ have been set) adjust according to the following equation:

$$
P_{t}=P_{t-1}\left[1+\gamma\left(\frac{e_{t-1}-e_{t-2}}{e_{t-2}}\right)\right]
$$

Where $e_{t}$ is the exchange rate in period $t$ and $\gamma$ captures the pass-through (Ball, 1998, provides a justification for an equation similar to A4). We also assume that arbitrage between investors yields the following uncovered interest parity condition:

$$
1+i_{t}=\left(1+i_{t}^{*}\right) \frac{E\left(e_{t+1}\right)}{e_{t}}
$$




\section{PREFERENCE OF THE CENTRAL BANK}

The Central Bank sets the interest rate (and, through the interest rate parity condition of Equation A5, the exchange rate) such that to minimize the following Barro-Gordon (1982) loss function:

$$
L_{t}=\frac{\theta}{2} \pi_{t}^{2}+\frac{\lambda}{2}\left(Y_{t}-Y^{c}\right)^{2}
$$

$\pi_{t}$ is inflation at time $t$ (we assume that target inflation is zero) and $Y^{c}$ is target income. We assume that there is no inflation bias ${ }^{20}$. Hence, if there are no shocks, the loss function (A6) will be minimized for $i_{t}=i^{*}$ and $e_{t}=e_{t-1}$.

Let us now study how the Central Bank reacts to shocks. We consider two kinds of shocks. The first is a real shock $\left(\xi_{t}\right)$ that reduces the marginal productivity of capital. In particular we can include the shock into Equation (A1) and obtain:

$$
Y_{t}=\left(\sigma_{t}-\xi_{t}\right)\left(1+\mu\left(i_{t-1}\right)\right) W_{t}
$$

The nominal shock $\left(\varepsilon_{t}\right)$ affects instead the Uncovered interest rate parity condition:

$$
1+i_{t}=\left(1+i^{*}\right) \frac{E\left(e_{t+1}\right)}{e_{t}}+\varepsilon_{t}
$$

There are several interpretations for Equation (A8). Aghion et al. (2000) think of $\varepsilon_{t}$ as an increase in country risk or an increase in expected devaluation (that would jump away from 0). An alternative interpretation is an increase in the foreign interest rate. For the purpose of our model, all these interpretations are observationally equivalent. Let us now describe the timing of events.

At the beginning of period 1 , prices $P_{1}=P_{0}=e_{0}=1$ are preset and firms invest. Domestic debts are contracted at the domestic rate $i_{0}$ (because this is the best forecast of $i_{1}$ ). Foreign currency debt is contracted at the foreign interest rate $i^{*}$. After investment decisions are made and debt contracts are signed, an

\footnotetext{
${ }^{20}$ This is equivalent to say that $Y^{c}$ is the income that would be produced at the natural rate of unemployment.
} 
unanticipated shock occurs. The shock can be either real $\xi$ or nominal $\varepsilon$ (or both). After the shock is realized, the Central Bank implements a monetary adjustment and sets the interest rate $i_{1}$. The market responds by setting the exchange rate $e_{1}$.

Figure 1 plots the composition of the demand and supply of funds and describes the adjustment process. On the horizontal axis we have the share of domestic debt and on the vertical axis the domestic interest rate. As, we assume that the composition of supply of funds is exogenous, the supply curve can be represented by a vertical line crossing the horizontal axis at $\left(1-\kappa^{*}\right)$. The relative demand for domestic funds depends negatively on the domestic interest rate and positively on the foreign interest rate and expected devaluation.

Let suppose that markets are in equilibrium at the initial foreign and domestic interest rate $i^{\star}$ and that expected devaluation is zero (i.e., $E\left(e_{2} / e_{1}\right)=1$ ). Now, suppose that there is an external shock. The foreign interest rate increases to $i * *$ and the demand of funds jumps to $D^{\prime}$. At the going domestic interest rate, there is now an excess demand for domestic funds. This excess demand will exert a pressure for an increase in domestic interest rate. If the Central Bank decides that the domestic interest rate should stay unchanged, the market will clear by making the exchange rate jump to a higher level $\left(e_{1}^{\prime}\right)$. If $\gamma$ is less than one, the devaluation will generate an expected appreciation (i.e., $\left.E\left(e_{2}^{\prime} / e_{1}^{\prime}\right)<1\right)$ and allow to keep the domestic interest rate at $i *$. Alternatively, the Central Bank may decide to leave the exchange rate untouched and let the interest rate move to its new level $i^{\star \star}$. Obviously, the Central Bank may choose any level of the interest rate (even below $i^{*}$ or above $i^{* *}$ ) and the market will respond with a corresponding jump in $e_{1}$.

After $i_{1}$ and $e_{1}$ have been set, profits for period one are realized, debt for period two is contracted, and output for period 2 is determined. Notice that, within the framework of Equation (A3), the exchange rate directly affects output through its effect on profits (this effect would be zero if there were no dollar denominated liabilities or if pass-through were complete) and indirectly through the effect of interest rate on the credit multiplier. The first is the balance sheet channel and the second is the credit channel ${ }^{21}$. We assume that at the end of period 2 , the economy is back in equilibrium and, since PPP is restored, $e_{2}$ is equal to $P_{2}$.

\footnotetext{
${ }^{21}$ Notice that, in the model discussed in this appendix, the exchange rate does not affect income through a competitiveness effect. By including competitiveness into Equation (A1), we would find that exchange rate affects output through three channels (credit channel, balance sheet channel, and competitiveness channel) but this wold not change the results discussed below.
} 


\section{THE OPTIMAL RESPONSE OF THE CENTRAL BANK}

To study the optimal reaction of the Central Bank let us substitute Equations (A3), (A4), (A7), and (A8) into the Central Bank's loss function A6 and write the Central Bank's problem as:

$$
\min _{e_{1}} L_{2}=\frac{\theta}{2}\left[\gamma\left(e_{1}-1\right)\right]^{2}+\frac{\lambda}{2}\left\{\left[S_{2}\left(\left(1+i^{*}\right) \frac{1+\gamma\left(e_{1}-1\right)}{e_{1}}+\varepsilon_{t}-1\right)-\xi_{t}\right]\left[Y_{1}-\left(1+i^{*}\right) D_{1}\left(1+\kappa\left(e_{1}-1\right)\right)\right]\right\}
$$

Notice that, as $e_{1}$ and $i_{1}$ are linked by Equation (A7), the two instruments are equivalent and we can express Equation (A9) as a function of either instrument. We choose $e_{1}$ because this simplifies the algebra. We can now minimize Equation (A9) with respect to $e_{1}$ and obtain the following first order condition:

$$
\begin{aligned}
& \frac{\partial L_{2}}{\partial e_{1}}=\theta \gamma^{2}\left(e_{1}-1\right)-\lambda\left(Y_{2}-Y^{c}\right)\left(1+i^{*}\right) S_{2}^{\prime} \frac{1-\gamma}{\left(e_{1}\right)^{2}}\left[Y_{1}-\left(1+i^{*}\right) D_{1}\left(1+\kappa\left(e_{1}-1\right)\right)\right]+ \\
& -\lambda\left(Y_{2}-Y^{c}\right)\left(1+i^{*}\right) \kappa D_{1}\left[S_{2}\left(\left(1+i^{*}\right) \frac{1+\gamma\left(e_{1}-1\right)}{e_{1}}+\varepsilon_{1}-1\right)-\xi_{1}\right]=0
\end{aligned}
$$

The first term of Equation A10 is the effect of the devaluation on inflation. The second and third terms are the effects of devaluation on output. To better understand the last two terms of Equation (A10) let us write $Y_{2}-Y^{c}=Y_{2}\left(i_{1}\left(e_{1}\right), e_{1}, \gamma, \xi_{1}, \varepsilon_{1}, \kappa, D_{1}\right)-Y^{c}$. Then, the second and third terms of Equation (A10) can be written as: $\lambda\left(Y_{2}-Y^{c}\right)\left(1+i^{*}\right)\left(\frac{\partial Y_{2}}{\partial i_{1}} \frac{\partial i_{i}}{\partial e_{1}}+\frac{\partial Y_{2}}{\partial e_{1}}\right)$. As, $\left(\partial Y_{2} / \partial i_{1}\right)\left(\partial i_{i} / \partial e_{1}\right)>0$ and $\partial Y_{2} / \partial e_{1}<0$, the sign of $\left[\left(\partial Y_{2} / \partial i_{1}\right)\left(\partial i_{i} / \partial e_{1}\right)+\left(\partial Y_{2} / \partial e_{1}\right)\right]$ is uncertain. The first term captures the credit channel the second term the balance sheet channel. If the credit channel dominates the balance sheet channel, devaluation are expansionary. In this case the Central Bank will react to a shock by devaluing the exchange rate, but, as devaluations have a cost in terms of inflation, the Central Bank cannot go all the way and leave the interest rate untouched (that is devaluation will not 
compensate totally the shock $\xi$ or $\varepsilon$ ). Hence, the Central Bank will both devalue and increase interest rate re $^{22}$.

It is clear that the relative use of the two instruments depends on the size of $\left(\partial Y_{2} / \partial i_{1}\right)\left(\partial i_{i} / \partial e_{1}\right)+\left(\partial Y_{2} / \partial e_{1}\right)$. If this is large, the exchange rate will move more than the interest rate, but as $\left(\partial Y_{2} / \partial i_{1}\right)\left(\partial i_{i} / \partial e_{1}\right)+\left(\partial Y_{2} / \partial e_{1}\right)$ goes to zero, interest rate adjustments will dominate exchange rate adjustments ${ }^{23}$.

Notice that if $\left[\left(\partial Y_{2} / \partial i_{1}\right)\left(\partial i_{i} / \partial e_{1}\right)+\left(\partial Y_{2} / \partial e_{1}\right)\right]<0$ devaluations are contractionary and hence the Central Bank will respond to a negative shock with a restrictive monetary policy that will lead to high level of the interest rate (above $\left.i^{\star *}\right)$ and to an appreciation of the exchange rate.

Concluding, the relative volatility of the interest rate and the exchange rate
will depended $\quad$ on the magnitude $\left(\frac{\partial Y_{2}}{\partial i_{1}} \frac{\partial i_{i}}{\partial e_{1}}+\frac{\partial Y_{2}}{\partial e_{1}}\right)=S_{2}^{\prime} \frac{\gamma-1}{\left(e_{1}\right)^{2}} \frac{Y_{2}}{S_{2}-\xi_{1}}-\kappa D_{1}\left(S_{2}-\xi_{1}\right)$ and hence on the degree of pass-through $(\gamma)$, the degree of liability dollarization $(\kappa)$, the effect of interest rate on the credit multiplies $\left(S^{\prime}\right)$, and on the magnitude of the shocks.

Notice that, contrary to the standard result according to which nominal shocks require an interest rate adjustment and real shocks an exchange rate adjustment, we find that both real and nominal shocks may require interest rate and exchange rate adjustments. The relative size of the adjustment will depend on pass-through and liability dollarization. In particular, countries with high passthrough and high levels of dollar liabilities will tend to adjust the interest rate more than the exchange rate, no matter what kind of shock they are facing.

\footnotetext{
22 Interest rate would be untouched only in the case in which $\gamma=0$ i.e. if there is no passthrough. At the same time, exchange rate would be untouched if $\gamma=1$.

${ }^{23}$ If $\left[\left(\partial Y_{2} / \partial i_{1}\right)\left(\partial i_{i} / \partial e_{1}\right)+\left(\partial Y_{2} / \partial e_{1}\right)\right]=0$ the whole shock will be absorbed by the interest rate.
} 


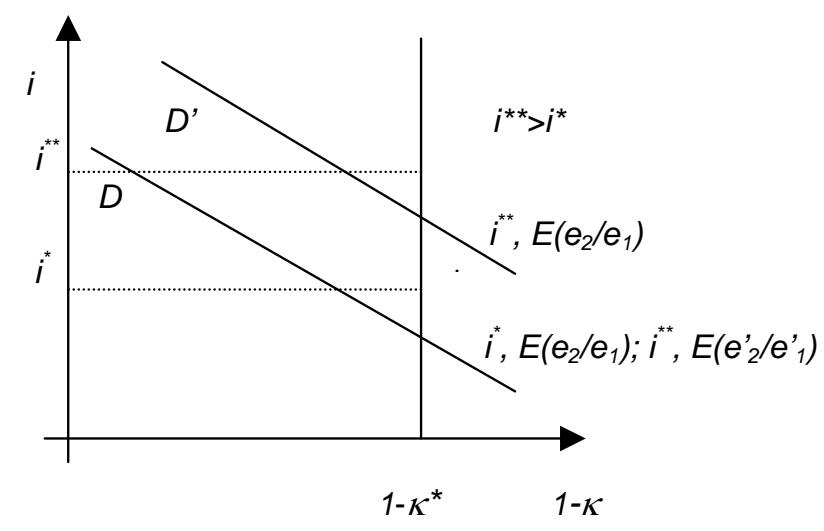

DYNAMICS

The above discussion is based on the assumption that the Central Bank is only concerned with inflation and output in period 2. However, in our model, shocks are persistent. Production in period 3 depends both directly and indirectly (through production in period 2) on $i_{1}$ and $e_{1}$ and production in period $t>3$ will indirectly depend on $i_{1}$ and $e_{1}$ though production in period $t-1$. As this paper is essentially empirical, the model provided in this Appendix is only meant to give an heuristic interpretation of what we find in the empirical analysis. Therefore, we will not attempt to solve for the dynamics of the model. In what follows we only look at what are the conditions under which the results derived in the previous section are robust to an intertemporal specification of the model.

With persistent shocks the one period loss function described in Equation (A6) is not appropriate. We should instead model the preferences of the Central Bank with the following intertemporal utility function:

$$
L_{2}=\sum_{t=2}^{t=\infty} \beta^{t-2}\left[\frac{\theta}{2} \pi_{t}^{2}+\frac{\lambda}{2}\left(Y_{t}-Y^{c}\right)\right]
$$

With $\beta=\frac{1}{1+\rho}$, where $\rho$ is the Central Bank's rate of time preference. By minimizing (A11) with respect to $e_{1}$ and doing some algebra, we obtain: 


$$
\frac{\partial L_{2}}{\partial e_{1}}=\theta \pi_{2} \frac{d \pi_{2}}{d e_{1}}+\lambda \frac{d Y_{2}}{d e_{1}}\left(Y_{2}-Y^{c}\right)+\lambda \sigma(1+\mu) \frac{d \Pi_{2}}{d e_{1}} \sum_{t=3}^{t=\infty} \beta^{t-2} A^{t-3}\left(Y_{t}-Y^{c}\right)=0
$$

Where $\Pi_{2}$ are profits in period 2 and $A=\left[\sigma+\mu\left(\sigma-\left(1+I^{*}\right)\right)\right]$. Notice that the first two terms of Equation (A12) are identical to Equation (A10). The difference between the one-period loss function of Equation (A6) and the intertemporal loss function of Equation (A11) is captured by the third term of Equation (A12).

The key issue in solving the above first order condition is to decide what is the target income $Y^{c}$. If, after the shock, the Central Bank readjust its target income and, for $t>2$, makes it conditional to the realization of $Y_{2}$ we get that, for $t>2, Y_{t}=Y^{c}$ and Equation (A12) reduces to Equation (A10). If the Central Bank never readjusts its target, $Y_{t^{-}} Y^{c}=h$ (where $h$ is a constant), no clear predictions can be made without assumptions on the parameters of the model and on the functional form of $\mu$. 
Table 1A: Absolute and relative volatilities, and country rankings

\begin{tabular}{|c|c|c|c|c|c|c|c|c|c|c|}
\hline \multirow[b]{2}{*}{ Country } & \multicolumn{2}{|c|}{ Devaluation } & \multicolumn{2}{|c|}{ Reserves } & \multicolumn{2}{|c|}{ Interest Rate } & \multicolumn{2}{|c|}{$\begin{array}{l}\text { Rel. } \\
\text { Intilition }\end{array}$} & \multicolumn{2}{|c|}{ Rel. } \\
\hline & (1) & $R$ & (2) & $R$ & (3) & $R$ & $(1) /(2)$ & $R$ & $(1) /(3)$ & $R$ \\
\hline Australia & 0.030 & 12 & 0.0043 & 26 & 0.0003 & 25 & 6.91 & 5 & 90.21 & 3 \\
\hline Brazil & 0.067 & 3 & 0.0231 & 16 & 0.0056 & 3 & 2.92 & 8 & 12.13 & 24 \\
\hline Canada & 0.017 & 24 & 0.0050 & 24 & 0.0007 & 22 & 3.37 & 7 & 23.46 & 12 \\
\hline Chile & 0.015 & 26 & 0.0357 & 8 & 0.0019 & 11 & 0.42 & 25 & 7.96 & 27 \\
\hline Colombia & 0.029 & 13 & 0.0317 & 11 & 0.0035 & 7 & 0.93 & 19 & 8.48 & 26 \\
\hline Czech & 0.034 & 8 & 0.0269 & 14 & 0.0024 & 8 & 1.26 & 16 & 13.97 & 20 \\
\hline Dominican Rep. & 0.024 & 18 & 0.0152 & 19 & 0.0021 & 9 & 1.58 & 14 & 11.57 & 25 \\
\hline Germany & 0.027 & 14 & 0.0095 & 23 & 0.0002 & 29 & 2.84 & 9 & 157.91 & 2 \\
\hline Greece & 0.023 & 19 & 0.0587 & 3 & 0.0009 & 21 & 0.39 & 28 & 25.02 & 9 \\
\hline Guatemala & 0.013 & 28 & 0.0320 & 10 & 0.0005 & 24 & 0.42 & 26 & 24.94 & 10 \\
\hline India & 0.015 & 27 & 0.0124 & 22 & 0.0041 & 6 & 1.21 & 17 & 3.70 & 29 \\
\hline Indonesia & 0.194 & 1 & 0.0899 & 1 & 0.0083 & 1 & 2.15 & 13 & 23.38 & 13 \\
\hline Israel & 0.026 & 16 & 0.0342 & 9 & 0.0012 & 19 & 0.76 & 21 & 21.38 & 15 \\
\hline Jamaica & 0.005 & 30 & 0.0200 & 17 & 0.0020 & 10 & 0.27 & 30 & 2.75 & 30 \\
\hline Japan & 0.044 & 6 & 0.0014 & 28 & 0.0001 & 30 & 30.45 & 1 & 377.26 & 1 \\
\hline Korea & 0.064 & 4 & 0.0477 & 5 & 0.0045 & 4 & 1.35 & 15 & 14.14 & 19 \\
\hline Mexico & 0.030 & 11 & 0.0358 & 7 & 0.0043 & 5 & 0.84 & 20 & 6.99 & 28 \\
\hline New Zealand & 0.033 & 9 & 0.0026 & 27 & 0.0014 & 18 & 12.68 & 4 & 23.78 & 11 \\
\hline Norway & 0.019 & 21 & 0.0537 & 4 & 0.0016 & 14 & 0.36 & 29 & 12.34 & 23 \\
\hline Paraguay & 0.019 & 20 & 0.0316 & 12 & 0.0016 & 15 & 0.62 & 23 & 12.38 & 22 \\
\hline Peru & 0.016 & 25 & 0.0315 & 13 & 0.0012 & 20 & 0.51 & 24 & 13.13 & 21 \\
\hline Philippines & 0.054 & 5 & 0.0234 & 15 & 0.0014 & 17 & 2.32 & 11 & 38.50 & 8 \\
\hline Poland & 0.026 & 15 & 0.0630 & 2 & 0.0018 & 12 & 0.42 & 27 & 14.58 & 18 \\
\hline Singapore & 0.030 & 10 & 0.0437 & 6 & 0.0015 & 16 & 0.69 & 22 & 20.00 & 16 \\
\hline South Africa & 0.036 & 7 & 0.0147 & 20 & 0.0016 & 13 & 2.47 & 10 & 22.80 & 14 \\
\hline Sweden & 0.019 & 22 & 0.0196 & 18 & 0.0003 & 26 & 0.98 & 18 & 62.59 & 5 \\
\hline Switzerland & 0.011 & 29 & 0.0049 & 25 & 0.0003 & 27 & 2.27 & 12 & 40.43 & 7 \\
\hline Thailand & 0.087 & 2 & 0.0132 & 21 & 0.0058 & 2 & 6.62 & 6 & 15.16 & 17 \\
\hline United Kingdom & 0.025 & 17 & 0.0014 & 29 & 0.0005 & 23 & 17.95 & 3 & 46.54 & 6 \\
\hline United States & 0.018 & 23 & 0.0009 & 30 & 0.0003 & 28 & 19.38 & 2 & 69.63 & 4 \\
\hline
\end{tabular}

(1) Std. Dev. (2) Std. Dev. (3) Std. Dev.

R: Ranking 
Why do countries float the way...

Table 2A: Other variables used in the regressions

\begin{tabular}{|c|c|c|}
\hline & Months floating & $L Y \& S$ \\
\hline Australia & 189 & 1 \\
\hline Brazil & 5 & 3 \\
\hline Canada & 359 & 1 \\
\hline Chile & 91 & 1 \\
\hline Colombia & 1 & 1 \\
\hline Czech Republic & 26 & $\mathrm{Na}$ \\
\hline Dominican Republic & 32 & 1 \\
\hline Germany & 323 & 1 \\
\hline Greece & 298 & 3 \\
\hline Guatemala & 118 & 1 \\
\hline India & 250 & 1 \\
\hline Indonesia & 23 & 3 \\
\hline Israel & 25 & 2 \\
\hline Jamaica & 122 & 3 \\
\hline Japan & 250 & 1 \\
\hline Korea South & 237 & $\mathrm{Na}$ \\
\hline Mexico & 56 & 1 \\
\hline New Zealand & 175 & 4 \\
\hline Norway & 80 & 4 \\
\hline Paraguay & 127 & 2 \\
\hline Peru & 109 & 3 \\
\hline Philippines & 180 & 1 \\
\hline Poland & 17 & 1 \\
\hline Singapore & 318 & $\mathrm{Na}$ \\
\hline South Africa & 250 & 1 \\
\hline Sweden & 81 & 2 \\
\hline Switzerland & 237 & 1 \\
\hline Thailand & 24 & 3 \\
\hline United Kingdom & 330 & 1 \\
\hline United States & 359 & 1 \\
\hline \multicolumn{3}{|c|}{ Regional Average } \\
\hline G3 & 310 & 1.0 \\
\hline Other Industrialized & 197 & 2.1 \\
\hline Emerging Countries & 109 & 1.7 \\
\hline Other Developing & 129 & 1.6 \\
\hline Lac Emerging & 52 & 1.8 \\
\hline East Asia & 157 & 1.2 \\
\hline All Countries & 170 & 1.8 \\
\hline
\end{tabular}


Figure 1

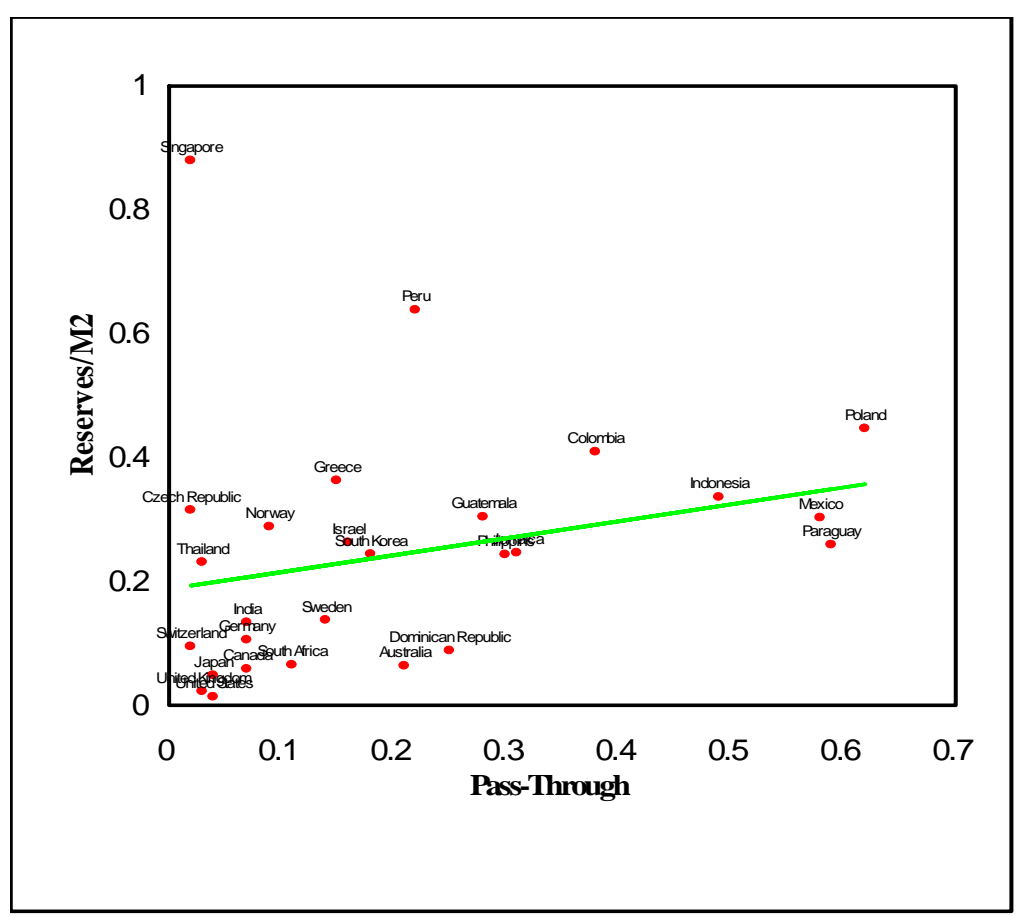


Why do countries float the way...

Figure 2

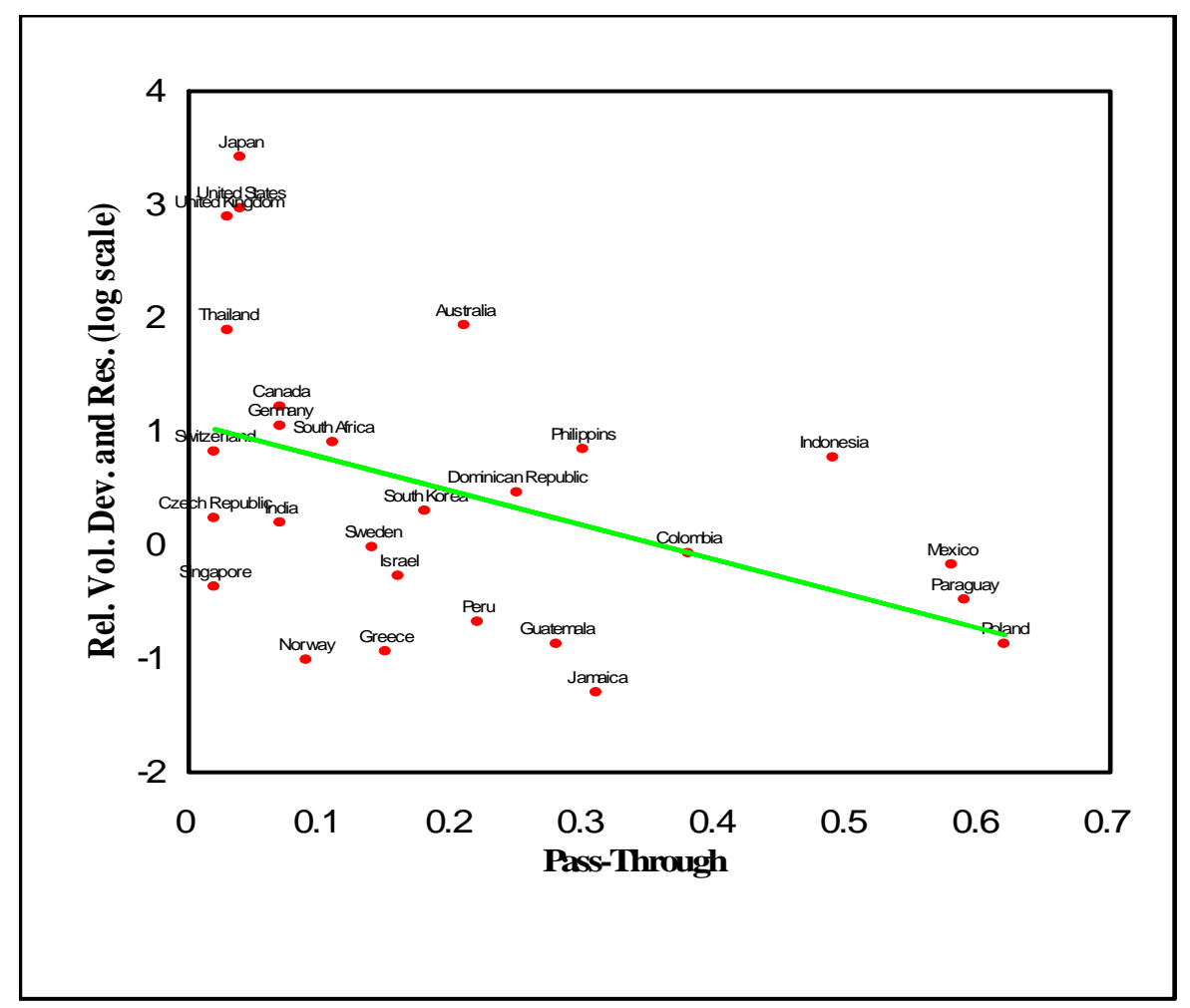


Figure 3

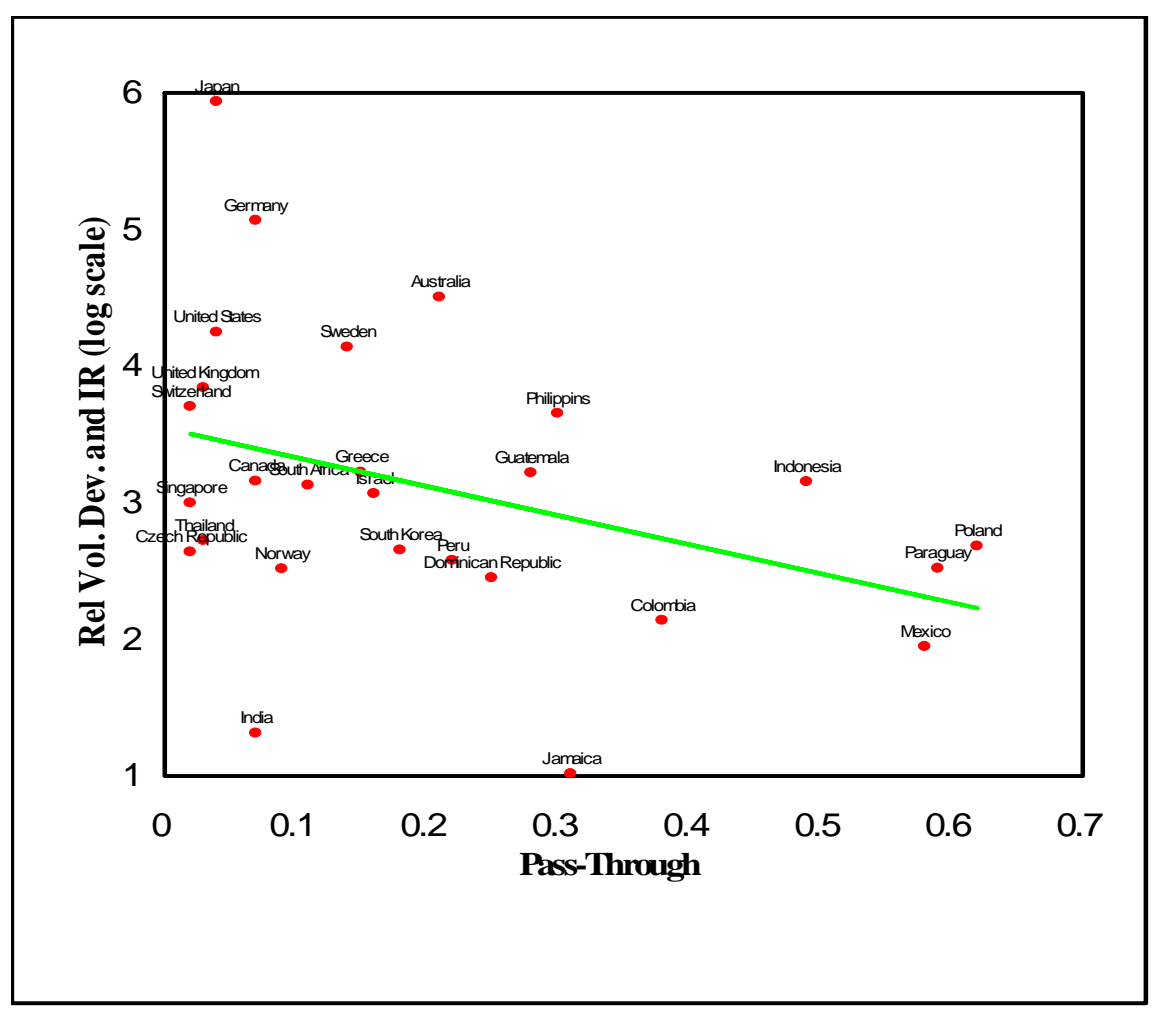


Figure 4

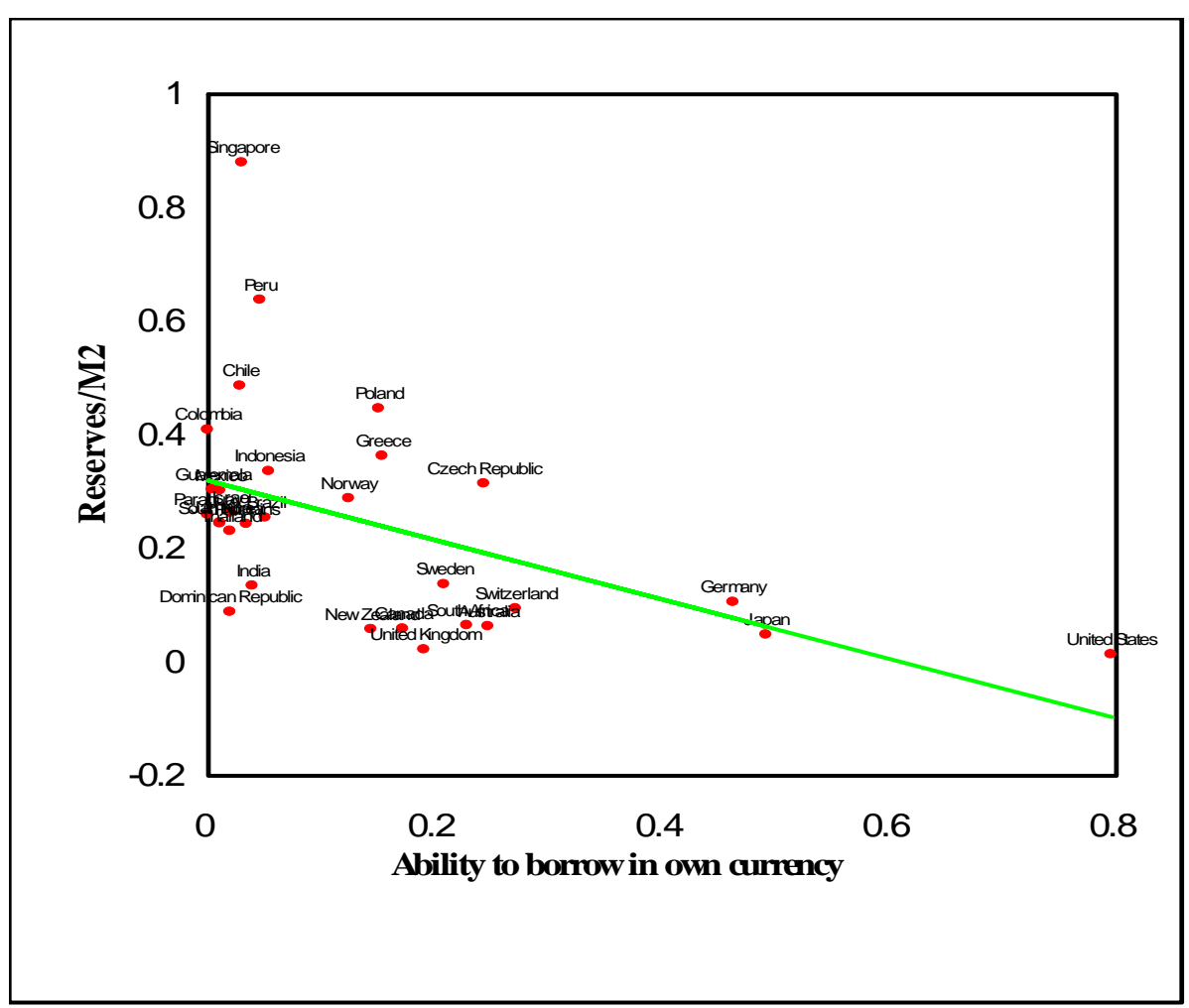


Figure 5

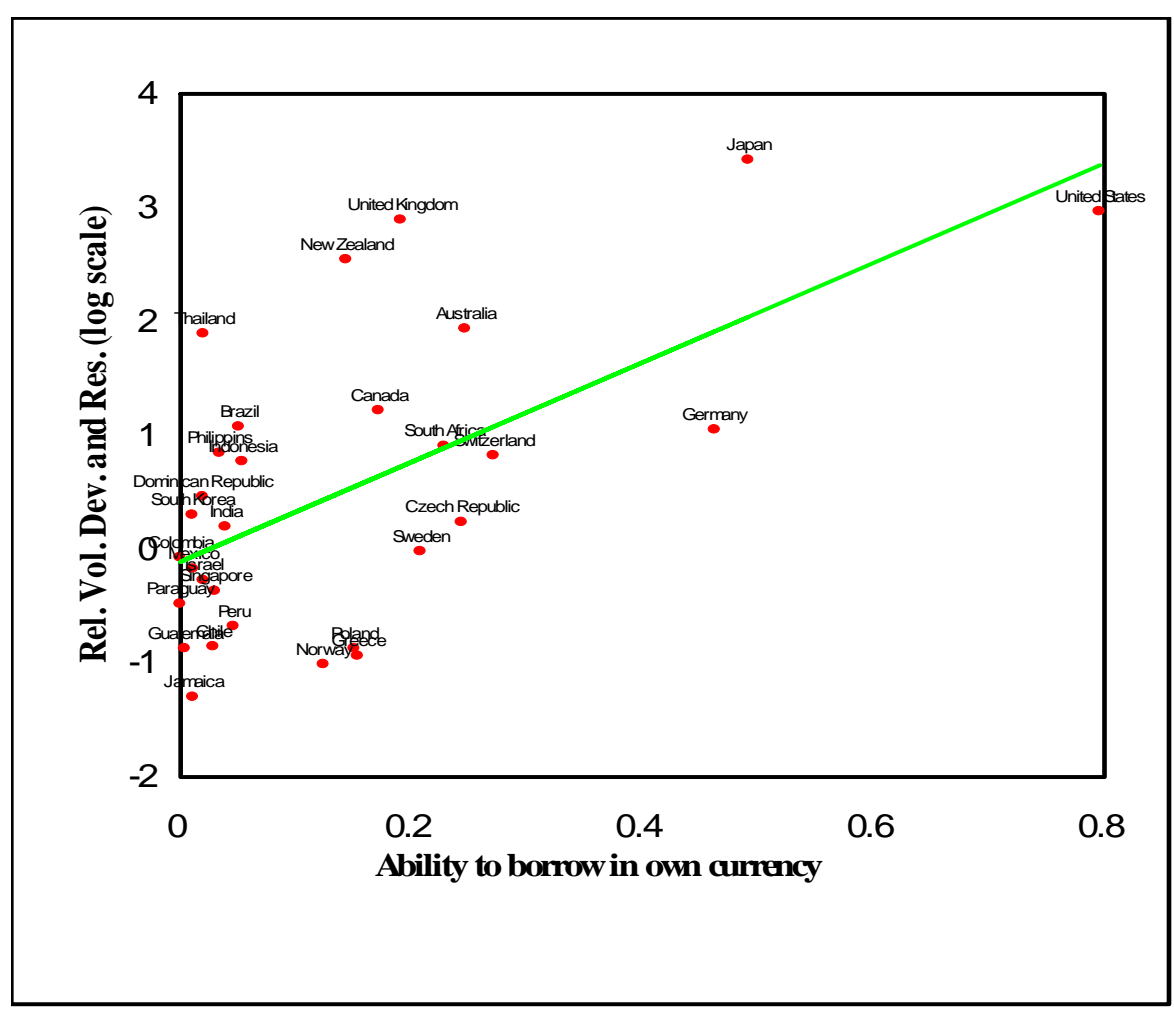


Why do countries float the way...

Figure 6

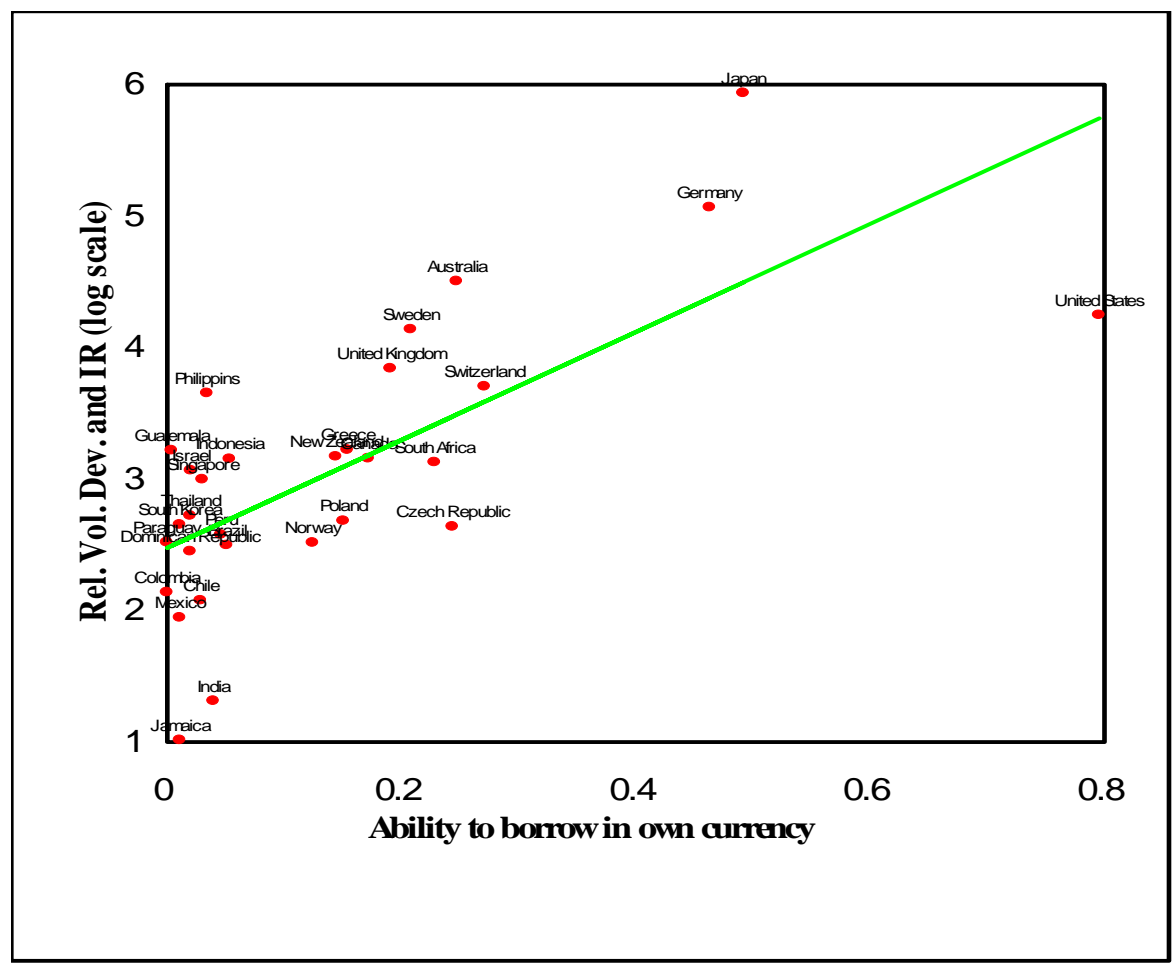




\section{REFERENCES}

Aghion, Philippe, Philippe Bacchetta and Abhijit Banerjee (1999), "Capital Markets and the Instability of Open Economies", CEPR Discussion Paper 2083.

-(2000), Currency Crises and Monetary Policy in an Economy with Credit Constraints, mimeo, UCL.

Bacchetta, Philippe (2000), Monetary Policy with Foreign Currency Debt, mimeo, University of Lausanne.

Ball, Laurence (1998), "Policy Rules for Open Economies," NBER Working Paper 6760.

De Brouwer, Gordon and Neil Ericsson (1995), "Modelling Inflation in Australia", Reserve Bank of Australia Research Discussion Paper 9510.

Calvo, Gulliermo (1999a), On Dollarization, mimeo, University of Maryland at College Park.

-(1999b), Capital Market and the Exchange Rate, with Special Reference to the Dollarization Debate in Latin America, mimeo, University of Maryland at College Park.

Calvo, Gulliermo and Carmen Reinhart (1999), "Capital Flow Reversals, The Exchange Rate Debate, and Dollarization", Finance and Development, September.

—(2000), Fear of Floating, mimeo, University of Maryland at College Park.

Edwards, Sebastian and Miguel Savastano (1999), "Exchange Rate in Emergeng Economies: What Do We Know? What Do We Need To Know?" NBER Working Paper 7228.

Fernández-Arias, Eduardo and Ernesto Talvi (1999), Devaluation or Deflation? Adjustment Under Liability Dollarization, mimeo, Inter-American Development Bank.

Frieden, Jeff, Piero Ghezzi and Ernesto Stein (1999), The Political Economy of Exchange Rate Policy in Latin America, mimeo, Inter-American Development Bank.

Garcés Diáz, Daniel (1999), “Determinación del Nivel de Precios y la Dinámica Inflacionaria en México", Documento de Investigación Económica, Banco de México.

Hausmann, Ricardo (1999a), "Should There Be Five Currencies or One Hundred and Five?" Foreign Policy, 116: 65-79.

Levy Yeyati, Eduardo and Federico Sturzenegger (1999), Classifying Exchange Rate Regimes: Deeds vs. Words, mimeo, Universidad Torcuato di Tella. 
McKinnon, R. (1963), "Optimum Currency Areas". American Economic Review. 53: 717725.

Morón, Eduardo, Edwin Goñi, and Arturo Ormeño (1999), Central Bankers Fear of Floating: The Peruvian Evidence, mimeo, Universidad del Pacifico.

Stein, Ernesto, Ernesto Talvi, Ugo Panizza and Gustavo Marquez (1999), Evaluando la Dolarización: Una Aplicación a Países de América Central y del Caribe, mimeo, InterAmerican Development Bank.

Svensson, Lars (1997) "Inflation Forecast Targeting: Implementing and Monitoring Inflation Targets," European Economic Review, 41: 1111-1146. 